\title{
Nitric Oxide as a Central Molecule in Hypertension: Focus on the Vasorelaxant Activity of New Nitric Oxide Donors
}

\author{
Gabriela Maria da Silva ${ }^{1}$, Mirelly Cunha da Silva ${ }^{1} \oplus$, Déborah Victória Gomes Nascimento ${ }^{1}$, \\ Ellen Mayara Lima Silva ${ }^{1}\left(\mathbb{D}\right.$, Fabíola Furtado Fialho Gouvêa ${ }^{2}$, Luiz Gonzaga de França Lopes ${ }^{3}$, \\ Alice Valença Araújo ${ }^{1}{ }^{\mathbb{D}}$, Kelli Nogueira Ferraz Pereira ${ }^{1}$ and Thyago Moreira de Queiroz ${ }^{1, *}$ (1)
}

1 Laboratory of Nutrition, Physical Activity and Phenotypic Plasticity, Federal University of Pernambuco, Vitória de Santo Antão 55.608-680, PE, Brazil; gabriela.mariasilva@ufpe.br (G.M.d.S.); mirelly.cunha@ufpe.br (M.C.d.S.); deborah.gnascimento@ufpe.br (D.V.G.N.); ellen.mayarasilva@ufpe.br (E.M.L.S.); alice.araujo@ufpe.br (A.V.A.); kelli.pereira@ufpe.br (K.N.F.P.)

2 School of Technical Health, Health Sciences Center, Federal University of Paraíba, João Pessoa 58.051-900, PB, Brazil; fabiola.fialho@academico.ufpb.br

3 Laboratory of Bioinorganic Chemistry, Department of Organic and Inorganic Chemistry, Federal University of Ceará, Fortaleza 60.020-181, CE, Brazil; lopeslu@dqoi.ufc.br

* Correspondence: thyago.queiroz@ufpe.br

Citation: da Silva, G.M.; da Silva, M.C.; Nascimento, D.V.G.; Lima Silva, E.M.; Gouvêa, F.F.F.; de França Lopes, L.G.; Araújo, A.V.; Ferraz Pereira, K.N.; de Queiroz, T.M. Nitric Oxide as a Central Molecule in Hypertension: Focus on the Vasorelaxant Activity of New Nitric Oxide Donors. Biology 2021, 10, 1041. https://doi.org/10.3390/ biology10101041

Academic Editor: Guo-Chang Fan

Received: 12 August 2021

Accepted: 9 October 2021

Published: 14 October 2021

Publisher's Note: MDPI stays neutral with regard to jurisdictional claims in published maps and institutional affiliations.

Copyright: (c) 2021 by the authors. Licensee MDPI, Basel, Switzerland. This article is an open access article distributed under the terms and conditions of the Creative Commons Attribution (CC BY) license (https:/ / creativecommons.org/licenses/by/ $4.0 /)$.
Simple Summary: Nitric oxide is an important molecule that performs a variety of functions in our bodies, especially in the cardiovascular system. In certain pathological conditions, such as cardiovascular diseases, including hypertension, there is reduced production or bioavailability of nitric oxide. Therefore, compounds that deliver nitric oxide, called nitric oxide donors, are clinically useful. In this review, we discuss the physiological role of nitric oxide, and some of the nitric oxide donors and their clinical uses, focusing on the cardiovascular system. Despite the high number of nitric oxide donors and their known efficacy, it is important to understand the similarities and differences among them and how each of them works, as well as to investigate the development of new molecules that may be better than the NO donors in current use.

Abstract: Cardiovascular diseases include all types of disorders related to the heart or blood vessels. High blood pressure is an important risk factor for cardiac complications and pathological disorders. An increase in circulating angiotensin-II is a potent stimulus for the expression of reactive oxygen species and pro-inflammatory cytokines that activate oxidative stress, perpetuating a deleterious effect in hypertension. Studies demonstrate the capacity of NO to prevent platelet or leukocyte activation and adhesion and inhibition of proliferation, as well as to modulate inflammatory or anti-inflammatory reactions and migration of vascular smooth muscle cells. However, in conditions of low availability of $\mathrm{NO}$, such as during hypertension, these processes are impaired. Currently, there is great interest in the development of compounds capable of releasing NO in a modulated and stable way. Accordingly, compounds containing metal ions coupled to NO are being investigated and are widely recognized as having great relevance in the treatment of different diseases. Therefore, the exogenous administration of NO is an attractive and pharmacological alternative in the study and treatment of hypertension. The present review summarizes the role of nitric oxide in hypertension, focusing on the role of new NO donors, particularly the metal-based drugs and their protagonist activity in vascular function.

Keywords: nitric oxide; vasodilation; oxidative stress; endothelium; NO donors

\section{Introduction}

Cardiovascular diseases (CVD) are the leading cause of death worldwide [1,2]. Hypertension remains the central risk factor for cardiovascular diseases [3], and a decrease in blood pressure (BP) induces a drop in cardiovascular risk [4]. However, the treatment for high BP is 
complex due to the multiple mechanisms involved in the pathogenesis of hypertension [5]. It has been shown that endocrine factors, and neural and vascular reflexes, contribute to the development of hypertension and induce an increase in vascular tone [6].

Regulation of vascular tone in the vascular smooth muscle cell (VSMC) is determined by the balance between vasoconstrictor and vasorelaxant factors [7]. Among the relaxing factors derived from the endothelium, nitric oxide (NO) stands out, as it has an important role in several pathophysiological processes, such as neurotransmission, BP control, and inhibition of platelet aggregation [8]. In addition, vascular endothelium has an important protective function against cardiovascular diseases, presenting a central function in this protection [9]. In the current review, we discuss the role of NO in hypertension, highlighting the importance of $\mathrm{NO}$ in the regulation of the vascular response and the use of the metalbased drugs that release NO.

\section{Hypertension and Endothelial Dysfunction}

CVD includes all types of disorders related to the heart or blood vessels. Among them, hypertension is one of the most important risk factors for heart complications and is responsible for high rates of morbidity, mortality, and hospitalization, at high cost [10]. Thus, hypertension is considered a serious public-health problem worldwide [11,12].

Hypertension is often associated with metabolic disorders, as well as functional and/or structural changes in target organs, and is exacerbated by the presence of other risk factors, such as dyslipidemia, obesity, glucose intolerance, and diabetes mellitus [13]. However, many factors are associated with these disorders and contribute directly or indirectly to the development of hypertension, including age, heredity, sex, ethnicity, social habits, stress, and others [14].

The prevalence of hypertension is increasing worldwide [2]. In 2015, 24.1\% of men and $20.1 \%$ of women were hypertensive and the number of cases increased from 594 million to 1.13 billion between 1975 and 2015 [15]. It is estimated that $29 \%$ of the adult population worldwide-around 1.56 billion individuals—will have hypertension by 2025 [16]. The prevalence is $33.1 \%$ in Nigeria [17], 19.9\% in Nepal [18], 30.6\% in France [19], and between 13.5 and $32.5 \%$ in Brazil [20-22]. In the United States, the prevalence of hypertension in adults reached $46 \%$ in 2017 [23].

An important factor of BP control is vascular tone, which is directly influenced by the vascular endothelium. Through its multiple functions, the endothelium maintains the homeostasis of the micro-environment since it is responsible for the production of potent vasoactive mediators [24]. The endothelium is a single layer of flat polygonal cells lining the inside of all blood vessels, including arteries, capillaries, veins, and chambers of the heart. It acts as a protective layer between intra- and extravascular compartments, enabling interaction with cells and blood components $[25,26]$.

Functions mediated by endothelial cells include maintenance of blood flow, regulation of inflammation and the immune response, neovascularization, and regulation of the vascular tone of the VSMC [27]. The VSMC may be regulated by endothelial cells which produce vasoconstrictor factors that promote their effects by increasing the concentration of intracellular calcium $\left(\left[\mathrm{Ca}^{2+}\right]_{i}\right)$, enhancing the sensitivity of $\mathrm{Ca}^{2+}$ contractile elements, and allowing $\mathrm{Ca}^{2+}$ influx from the extracellular fluid. Among the contractile factors released by the endothelium, we can highlight the thromboxane $\left(\mathrm{TXA}_{2}\right)$, reactive oxygen species (ROS) such as superoxide anion $\left(\mathrm{O}_{2}{ }^{-}-\right.$, endothelin-1 (ET-1), and angiotensin II (Ang-II) [28]. Vasodilator factors, meanwhile, have the opposite effect on $\left[\mathrm{Ca}^{2+}\right]_{i}$ in the VSMCs [7]. The three main relaxing factors derived from the endothelium are prostacyclin $\left(\mathrm{PGI}_{2}\right)$, endothelium-derived hyperpolarizing factor (EDHF), and NO. Endogenous production of $\mathrm{NO}$ is believed to be the main factor released by the endothelium for the control of vascular tone $[8,28,29]$. Furthermore, the vascular endothelium performs a key role in providing protection against cardiovascular diseases [9]. Damage to the endothelium generates an inflammatory response involving many types of cells (lymphocytes, monocytes, platelets, 
and smooth muscle), leading to dysfunction of the endothelial cells, impairment of the vascular wall, and development of an atherosclerosis plaque [30].

Endothelial dysfunction (ED) is characterized mainly by a reduction in the ability of endothelial cells to release NO, as determined by oxidative stress, the adhesion of leukocytes, the inflammatory response, platelet activation, and thrombosis [31]. Various other factors also induce ED, including: (1) uncoupling of the nitric oxide synthase (NOS); (2) formation of reactive nitrogen and oxygen species, reducing the bioavailability of $\mathrm{NO}$ and leading to nitration, nitrosylation, and oxidation of proteins; (3) oxidation or degradation of the $\alpha$ and $\beta$ subunits of soluble guanylyl cyclase (sGC), which is the primary mediator of the bioactivity of NO; (4) greater bioavailability of vasoconstrictor agents, such as ET-1 and Ang-II; (5) oxidation of low-density lipoprotein (LDL), inducing the formation of foam cells; (6) greater expression of adhesion molecules, and; (7) increased platelet activity [32].

Therefore, ED is a marker for cardiovascular diseases and is shown in several pathological conditions, including diabetes, arterial and pulmonary hypertension, hyperglycemia, arthritis, obesity, heart failure, and erectile dysfunction [33]. These alterations may lead to changes in vascular hemodynamics, resulting in loss of endothelial integrity, barrier dysfunction, and atypical vasodilator and vasoconstrictor regulation, thereby modifying the vascular environment, triggering cardiovascular events, and, subsequently, increasing mortality [34].

\section{Biosynthesis and Action of Nitric Oxide}

NO is a simple small gaseous molecule which has been found to be a ubiquitous biological mediator involved in several physiological processes and plays a key role in the nervous and cardiovascular systems [35]. The molecule, previously known as endothelium-derived relaxing factor (EDRF), was first identified as NO in 1980 [36]. It has been recognized to be a signaling molecule, derived from the vascular endothelium, responsible for dilation of the blood vessels $[37,38]$.

Since $\mathrm{NO}$ was pointed out as a signaling molecule in vascular relaxation, investigations have been conducted concerning the role of this gas in various biological systems in humans. NO spreads throughout the membrane and can exist in a variety of forms, such as nitroxyl anion $\left(\mathrm{NO}^{-}\right)$, nitrosonium $\left(\mathrm{NO}^{+}\right)$, or free radical (NO)), depending on the source of the $\mathrm{NO}[39,40]$.

$\mathrm{NO}$ is highly reactive and its relatively short half-life means that it is responsible for mediating many processes, such as endothelium-dependent vasorelaxation, platelet adhesion and aggregation, relaxation of the corpus cavernosum of the human penis, and regulation of baseline BP [41-43]. It also modulates inflammatory or anti-inflammatory reactions that help to regulate the numerous processes of immunological and cardiovascular systems $[44,45]$.

Biosynthesis of the NO molecule occurs by the oxidation of L-arginine catalyzed by NOS. There are three known isoforms of NOS: neuronal NOS (nNOS or NOS-I) is expressed in the cytoplasm of neurons and other cell types; endothelial NOS (eNOS or NOS-III) is present mainly in endothelial cells; nNOS and eNOS are constitutive isoforms. The third isoform is the inducible NOS (iNOS or NOS-II), which is mainly associated with macrophages, but has been isolated from various other tissues, such as smooth muscle, hepatocytes, chondrocytes, microglial cells, and endothelial cells, among others [46-53]. The iNOS-produced NO is responsible for augmented leucocyte cytotoxicity against tumoral cells, bacteria, and parasites during inflammation [54].

All NOS isoforms use L-arginine as substrate and produce citrulline as a co-product. Molecular oxygen is required for the reaction and the co-factors include reduced nicotinamide adenine dinucleotide phosphate (NADPH), flavin adenine dinucleotide (FAD), flavin mononucleotide (FMN), and 6R-5,6,7,8-tetrahydrobiopterin $\left(\mathrm{BH}_{4}\right)$ [55]. The homodimeric form of NOS is promoted/stabilized by the heme group, L-arginine, and $\mathrm{BH}_{4}[44,56,57]$. However, when $\mathrm{BH}_{4}$ is deficient due to oxidative inactivation, the dimer of 
NOS breaks down, generating ROS (especially $\mathrm{O}_{2}{ }^{\bullet-}$ ) instead of NO [58-61]. This state is referred to as eNOS uncoupling and also occurs downstream of NADPH activation, which induces oxidative stress and consequent $\mathrm{BH}_{4}$ deficiency and eNOS uncoupling [59,61]. Furthermore, the enhancement in ROS production can interact with NO and produce peroxynitrite $\left(\mathrm{ONOO}^{-}\right)$, decreasing the $\mathrm{NO}$ bioavailability and cell damage [30,62].

Despite the similarities, there are key differences between the constitutive and inducible NOS. Firstly, the constitutive NOS activity depends on the cell calcium transient, while the basal calcium concentration is enough to maintain the activity of iNOS. Binding of the calcium-calmodulin complex is required for constitutive NOS (although its function may also be regulated by post-transcriptional events) $[50,63,64]$, while iNOS presents the calcium-calmodulin permanently bound and its expression is mainly transcriptional controlled $[65,66]$. This leads to a transitory activation and low NO production by the constitutive isoforms, in contrast to long-lasting activation and high NO production by iNOS [67-70]. In addition, iNOS does not have the self-inhibition segment of the ligation site of calmodulin [71].

The expression of the inducible isoform is regulated by the induction of the synthesis of various cytokines, including interleukin 1 (IL-1), interferon- $\gamma$ (IFN- $\gamma$ ), and tumor necrosis factor $\alpha$ (TNF- $\alpha$ ) [72]. Lipopolysaccharide (LPS), an abundant molecule present in the cell wall from Gram-negative bacteria, induces cytokine production and, thus, iNOS expression [73,74]. In regular conditions, its expression is common in macrophages, where there is active inflammation, such as in alveolar macrophages in the inflamed regions of the lung [75].

The vascular relaxation stimulus coming from the endothelium begins after vasodilator agents bind to membrane receptors in the endothelial cell or from shear stress (via $\mathrm{PI}_{3} \mathrm{~K} / \mathrm{AKT}$-dependent eNOS phosphorylation) on the vascular endothelium. Once the membrane G-protein coupled receptors (GPCR) are activated by the binding of agonists, the phospholipase C (PLC) enzyme is activated, inducing a rise in diacylglycerol (DAG) inositol 1,4,5-trisphosphate $\left(\mathrm{IP}_{3}\right)$ production. $\mathrm{IP}_{3}$ acts on receptors expressed in the cytoplasmic reticulum, stimulating the release of $\mathrm{Ca}^{2+}$ to the cytoplasm. The increase in the concentration of $\mathrm{Ca}^{2+}$ in the cytoplasm activates calmodulin, which, in turn, activates eNOS, which is the predominant isoform in endothelial cells. Once activated, eNOS synthesizes the NO [76,77] (Figure 1).

NO possesses the peculiar characteristic of having high affinity for heme and other iron-sulfur groups, being able to react directly with oxygen, the superoxide radical, or transition metals, such as iron, cobalt, manganese, and copper. This property is of great importance for the activation of sGC $[78,79]$.

As shown in Figure 1, NO spreads throughout the endothelial cell, moving easily through the neighboring cells and regulating various cardiovascular effects. It crosses the endothelial space into the vascular smooth muscle, directly activating the sGC, which is the primary mediator of the bioactivity of $\mathrm{NO}$, representing the largest target in muscle cells [80]. The sGC enzyme is a heterodimer, consisting of two homologous subunits, $\alpha$ ( $\alpha 1$ and $\alpha 2$ ) and $\beta$ ( $\beta 1$ and $\beta 2$ ). The term NO-sensitive sGC has come to be used, since, apart from activating sGC, NO can also activate one of the dimers of GC ( $\alpha 2 \beta 1)$, which is found in the synaptic membrane [80].

The $\alpha 1 \beta 1$ dimer is the predominant isoform in most tissues, including VSMC [80,81]. In the $\beta$ subunit of the dimer, the iron of the heme group binds to histidine. Once NO binds to the iron of GC, the bond with the histidine is broken. This is considered the factor that triggers the increase in enzymatic activity of sGC [80,82]. Furthermore, the activation of sGC leads to the formation of intracellular 3,5-cyclic guanosine monophosphate (cGMP), which in turn activates the cGMP-protein kinase G (PKG) pathway [83-85]. PKG can phosphorylate voltage-dependent $\mathrm{Ca}^{2+}$ channels present in the cell membrane, which causes a reduction in the entry of $\mathrm{Ca}^{2+}$ into the cell, thereby altering the $\left[\mathrm{Ca}^{2+}\right]_{\mathrm{i}}$ dynamics and constrictor function $[86,87]$. 
PKG uses several mechanisms to reduce mobilization of $\mathrm{Ca}^{2+}$ through phosphorylation and inhibition of $\mathrm{IP}_{3}$ formation and inhibition of the sarcoplasmic reticulum (SR)-IP $\mathrm{IP}_{3}$ receptor. $\mathrm{NO}$ also causes an increase in $\mathrm{Ca}^{2+}$ transport through the (SR) $\mathrm{Ca}^{2+}$-ATPase, in a cGMPindependent mechanism [88]. Furthermore, PKG acts in phosphorylate potassium channels in the cell membrane, triggering an increase in transport of $\mathrm{K}^{+}$and consequent membrane hyperpolarization, thereby contributing to muscle relaxation [88]. Other ways in which PKG leads to smooth-muscle relaxation are through desensitization of the contractile filaments, inhibition of myosin light chain kinase (MLCK), and activation of myosin light chain phosphatase (MLCP) [89]. All of these effects lead to a reduced concentration of free $\mathrm{Ca}^{2+}$ in the cytoplasm and thus contribute to muscle relaxation (Figure 1). Moreover, PKG induces phosphorylation of vasoconstrictor targets such as $\mathrm{TXA}_{2}$ receptors, leading to a reduction in receptor activation and facilitating the vasorelaxant response [90].

Bolotina et al. (1994) found that NO also produces vasodilation through sGC-independent pathways. These mechanisms include activation of the large-conductance $\mathrm{Ca}^{2+}$-sensitive $\mathrm{K}^{+}$ channel ( $\mathrm{BK}_{\mathrm{Ca}}$ ); activation of $\mathrm{Na}^{+} / \mathrm{K}^{+}$ATPase; negative modulation of $\mathrm{Ca}^{2+}$ channels, and; reduced sensitivity to vasoconstrictors [91]. An interesting study showed that NO produces an increase in $\mathrm{BK}_{\mathrm{Ca}}$ activation by triggering rapid anterograde trafficking of $\mathrm{BK}_{\mathrm{Ca}} \beta 1$ subunitcontaining endosomes in a PKG/PKA-dependent pathway [92,93]. Alternatively, cGMP may also directly activate potassium channels [94].

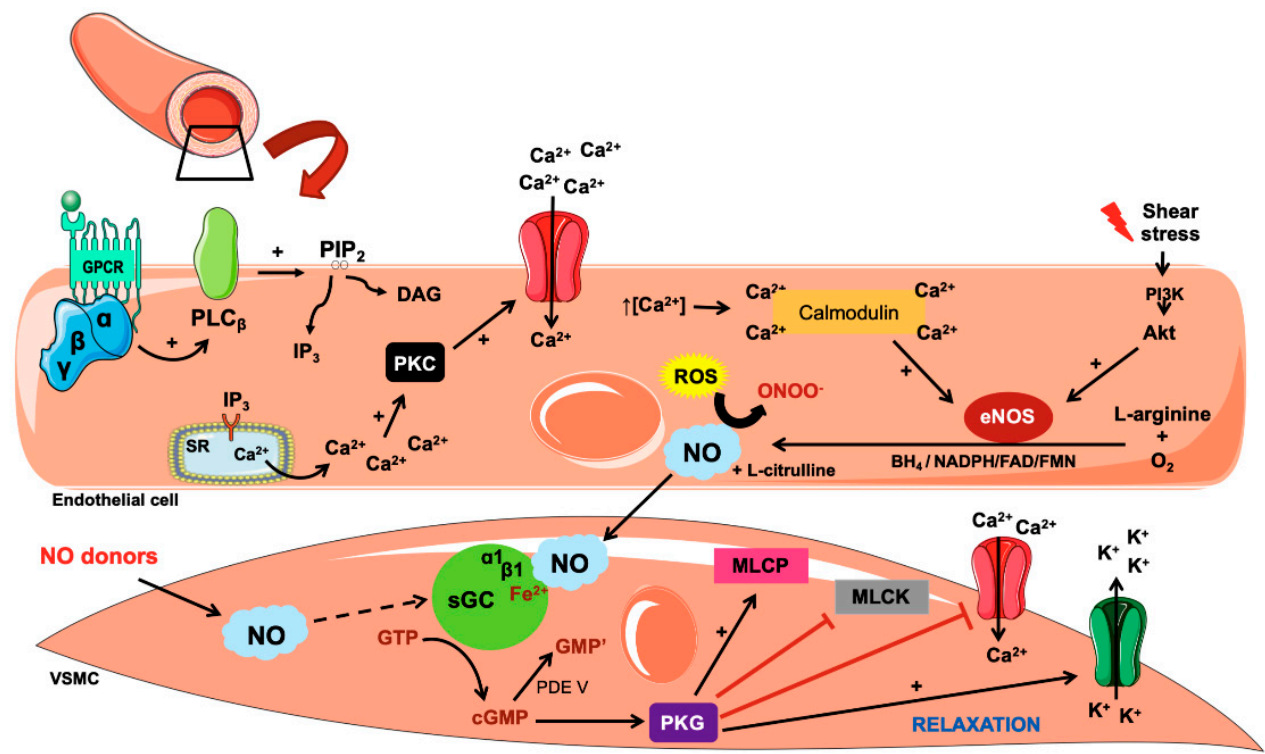

Figure 1. Nitric oxide (NO) induces relaxation in vascular smooth muscle cells (VSMC). The activation of G-protein coupled receptor (GPCR) stimulates phospholipase C (PLC), which is responsible for cleavage of membrane phospholipids to diacylglycerol (DAG) and inositol 1,4,5-trisphosphate $\left(\mathrm{IP}_{3}\right)$. The latter binds to the $\mathrm{IP}_{3}$ receptor in sarcoplasmic reticulum (SR) to promote $\mathrm{Ca}^{2+}$ extrusion, which, together with DAG, evokes $\mathrm{Ca}^{2+}$ influx through voltage-operated $\mathrm{Ca}^{2+}$ channels $\left(\mathrm{Ca}_{\mathrm{V}}\right)$ at the cellular membrane. The linkage of $\mathrm{Ca}^{2+}$ to calmodulin promotes endothelial nitric oxide synthase (eNOS) activation, which, in turn, triggers the formation of $\mathrm{NO}$ and citrulline from arginine and $\mathrm{O}_{2}$. This enzyme requires cofactors such as nicotinamide adenine dinucleotide phosphate (NADPH), flavin adenine dinucleotide (FAD), flavin mononucleotide (FMN), and tetrahydrobiopterin $\left(\mathrm{BH}_{4}\right)$. In case of an increase in reactive oxygen species (ROS), they react with $\mathrm{NO}$ and induce peroxynitrite $\left(\mathrm{ONOO}^{-}\right)$ production. NO spreads to VSMC where it binds to soluble guanylyl cyclase (sGC) and causes the formation of 3,5-cyclic guanosine monophosphate (cGMP), which stimulates the cGMP-protein kinase $\mathrm{G}(\mathrm{PKG})$. This kinase negatively regulates the $\mathrm{Ca}_{\mathrm{v}}$ and myosin light chain kinase (MLCK) and activates potassium channels and the myosin light chain phosphatase (MLCP). Altogether, these effects promote the relaxation of VSMC. In addition, NO can be produced from a GPCR-independent mechanism. The shear stress promotes activation of the $\mathrm{PI}_{3} \mathrm{~K} / \mathrm{AKT}$ pathway, which stimulates eNOS activation and subsequent NO production. 


\section{Mechanisms Involved in NO-Related Hypertension}

The balance between the levels of NO and Ang-II seems to be a central aspect in CVD, especially in the pathogenesis of hypertension [95]. Ang-II is the most potent vasoconstrictor of the renin-angiotensin system (RAS) [96]. The effects of Ang-II are mediated by its binding to angiotensin type $1\left(A_{1} R\right)$ and type $2\left(A_{2} R\right)$ receptors, which are $G$ protein-coupled receptors that induce contrary effects [97]. $A T_{1} R$ is responsible for the classic pro-hypertensive activity of Ang-II, while $\mathrm{AT}_{2} \mathrm{R}$ is described to present antagonistic activities compared to $\mathrm{AT}_{1} \mathrm{R}$ [98]. It has been shown that Ang-II (mainly by binding to $\mathrm{AT}_{1} \mathrm{R}$ ) directly induces endothelial dysfunction and increases endothelial oxidative stress through the formation of ROS derived from NADPH oxidase [99]. Furthermore, stimulation of $\mathrm{AT}_{1} \mathrm{R}$ was noted as causing inhibition of eNOS, principally by phosphorylation of an inhibitory residue Tyr657 [100,101]. However, exogenous administration of an NO donor stimulates $\beta$-arrestin, which leads to desensitization of $\mathrm{AT}_{1} \mathrm{R}$ through its internalization, antagonizing the Ang-II effects [102]. Likewise, another study has demonstrated that NO directly interacts with $\mathrm{AT}_{1} \mathrm{R}$, promoting its inhibition $[95,103]$. Furthermore, the addition of the exogenous NO precursor upregulated the eNOS/NO/cGMP pathway and decreased the Ang-II concentration in rats with left ventricular hypertrophy [104].

On the other hand, studies have revealed that Ang-(1-7) treatment reduced ROS formation due to a decrease in NADPH expression in the aorta of mice [105]. Moreover, evidence has shown that Ang-(1-7) induces Mas receptor (MasR) activation, a G protein-coupled receptor which stimulates the PI3K/Akt pathway, leading to phosphorylation of eNOS and subsequent NO production and release [106]. Similarly, Ang-(1-7) is able to promote $\mathrm{AT}_{2} \mathrm{R}$ endothelial activation, which stimulates the bradykinin (BK)-NO cascade [107-109]. $\mathrm{BK}$ is a component of the kallikrein-kinin system which acts as a counter regulator of the vasopressor RAS. BK acts through the $\mathrm{B} 2$ receptor and induces a decrease in ROS and NO production, enabling a reduction in BP [110].

Beyond the effect as an endothelial-dependent vasorelaxing factor, $\mathrm{NO}$ is also present in the brain and this gas acts as an intracellular signaling molecule and is involved in the modulation of sympathetic outflow and changes in BP [111]. Studies demonstrated that overexpression of eNOS in the nucleus of the solitary tract (NTS) or rostral ventrolateral medulla (RVLM) caused hypotension and bradycardia associated with sympathoinhibition in vivo $[112,113]$. In addition, recent findings have shown that NO derived from $\mathrm{nNOS}$ in the hypothalamic paraventricular nucleus $(\mathrm{PVN})$ plays a central role in suppressing both ongoing renal sympathetic activity and BP in awake rats $[114,115]$. However, NOS inhibition induced neurogenic hypertension [116]. Conversely, iNOS overexpression causes hypertension with sympathetic activation due to, probably, an inflammatory condition and an increase in ROS [117]. In addition, an elegant study observed that NO originated from eNOS can alter noradrenaline (NE) release from the sympathetic nerve, inhibiting the NE release in neural/vascular tissues, and decreasing the sympathetic tone [95,118].

The first evidence of an association between Ang-(1-7) and NO in the brain was from the discovery of a co-localization of the peptide with NOS in neurons of the PVN [119]. The overexpression of angiotensin converting enzyme type 2 (ACE2), the enzyme responsible for converting Ang-II into Ang-(1-7), in the PVN, stabilized the reduction in nNOS protein expression in the PVN in animals with chronic heart failure and was accompanied by improved sympathetic nerve activity, suggesting the participation of NO in the inhibitory effects of ACE2 in the sympathoexcitation [120,121].

As shown in Figure 2, all this evidence together suggests that an increase in NO, especially from eNOS and nNOS sources, in the periphery, including vascular, renal, and cardiac tissues, as well as in different regions of the central nervous system (CNS) such as the PVN, NTS, and RVLM, leads to activation of the sCG/PKG pathway and a decrease in oxidative stress, inducing downregulation of the sympathetic drive and consequent inhibition of a BP increase. Furthermore, the routes that involve these effects are related to non-classic RAS (ACE2/Ang-1-7/MasR/AT $2 \mathrm{R}$ ) cascade overexpression and Ang-II $/ \mathrm{AT}_{1} \mathrm{R} / \mathrm{ROS}$ pathway decline. 


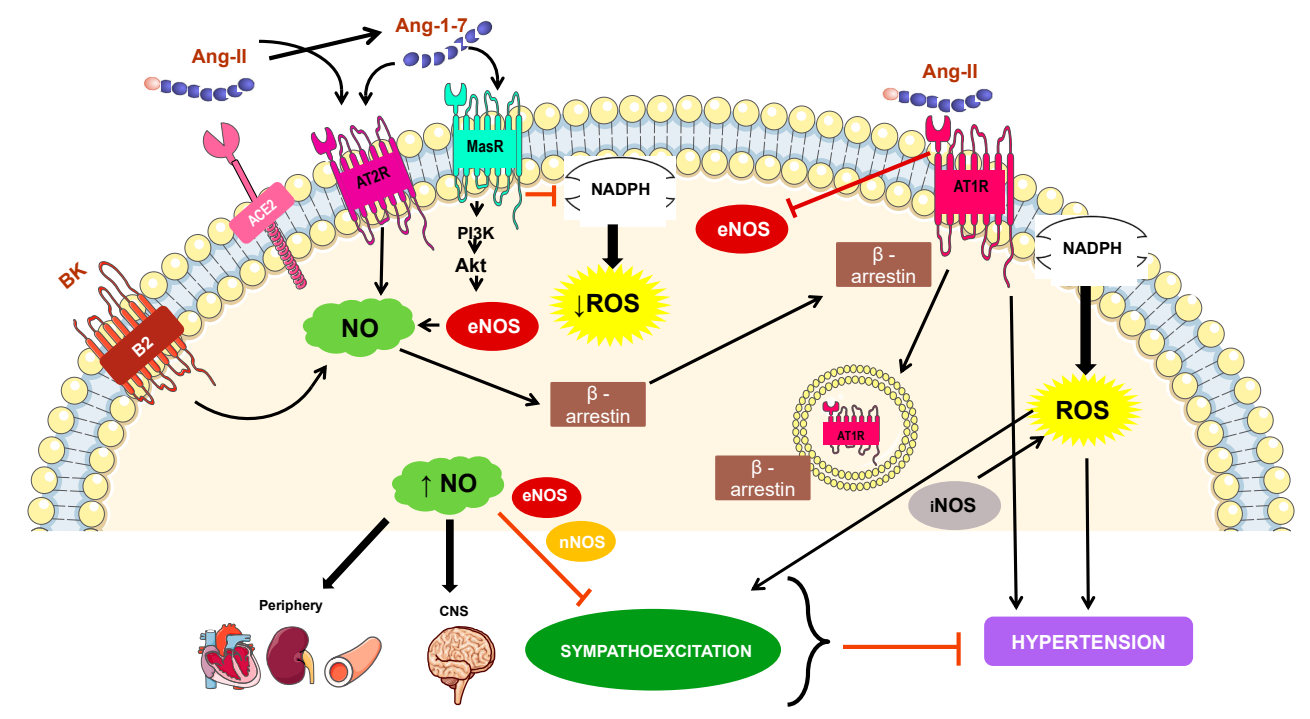

Figure 2. Mechanisms involved in NO-related hypertension. The effects of angiotensin II (Ang-II) are mediated by its binding to angiotensin type $1\left(\mathrm{AT}_{1} \mathrm{R}\right)$ and type $2\left(\mathrm{AT}_{2} \mathrm{R}\right)$ receptors. $\mathrm{AT}_{1} \mathrm{R}$ is responsible for the classic pro-hypertensive activity of Ang-II, including NADPH oxidase activation and reactive oxygen species (ROS) production. Ang-II undergoes the action of angiotensin converting enzyme type 2 (ACE2) into angiotensin 1-7 (Ang-(1-7)), which classically interacts with Mas receptor (MasR) and induces the PI3K/Akt pathway activation and consequent phosphorylation of eNOS. The activation of MasR also downregulates NADPH activity, reducing ROS levels. Furthermore, Ang-(1-7) can also bind to AT2R, which stimulates the bradykinin (BK)-NO cascade. It is important to highlight that, when activated, the BK targets such as the B2 receptors induce NO production. NO, in turn, is responsible for stimulating the $\beta$-arrestin pathway that promotes AT1R desensitization and internalization of the receptor. In summary, the increase in NO (from endothelial and neuronal nitric oxide synthase- - eNOS and nNOS, respectively) promotes a decrease in oxidative stress, inducing downregulation of sympathoexcitation and consequent inhibition of BP increase in both periphery and different areas of the central nervous system (CNS). Conversely, NO derived from inducible NOS (iNOS) is involved in the rise in sympathetic tonus and ROS production, mechanisms related to triggering hypertension.

\section{Nitric Oxide Donors}

The reduced synthesis and/or bioavailability of NO are associated with many CVDs, including arterial hypertension, atherosclerosis, coronary diseases, and angina [122]. Regarding the properties of $\mathrm{NO}$, a large number of $\mathrm{NO}$ donor compounds have emerged as potential agents for the treatment of the aforementioned diseases, able to exploit the wide variety of biological functions. Thus, pharmacological aspects of $\mathrm{NO}$ are constantly under study [45,123-127]. Furthermore, administration of drugs that mimic the effect of NO on the organism is an attractive proposal, since this is a pharmacological alternative that could reverse and/or prevent cardiovascular disorders [125].

The pathways for the formation and consequent release of NO differ significantly depending on the class of compounds and their reactivity [123]. The amount of NO released by a donor is one important factor, since cardiovascular action only occurs at very low concentrations and higher concentrations are toxic [128]. Some NO donor compounds require a catalytic enzyme to release $\mathrm{NO}$, while others release $\mathrm{NO}$ spontaneously, without an enzyme. On the other hand, other NO donors need an interaction with thiol groups, some being reduced, and others oxidized, but all depend on the exposure time [123,129].

Prospection of nitrosylated compounds has emerged as a possible source for the formation of NO-releasing agents in biological targets, which could induce the relaxation of the vascular smooth muscles. Due to the endothelial dysfunction that occurs in some 
pathologies, NO donors have been developed to overcome the deficiency in this molecule, although some tolerance to organic nitrates has been reported [130].

\subsection{Sodium Nitroprusside (SNP)}

One of the best-known NO donors is sodium nitroprusside (SNP), which presents a short half-life and high reactivity with oxygen [38]. SNP is an inorganic complex used, since 1928, as a vasodilator in hypertensive crisis and cardiovascular emergencies, such as angina pectoris and heart failure [131-133]. SNP also provides a controlled hypotensive effect during surgery [134]. Furthermore, SNP is frequently employed as a nitrovasodilator prototype in pharmacological studies. However, provision of NO from SNP requires only light irradiation or the reduction of one electron [123,134].

The main clinical limitation of SNP is the release of NO accompanied by the release of cyanide $\left(\mathrm{CN}^{-}\right)$, which forms part of its structure, making it highly toxic to the organism and causing long-term treatment to lead to endothelial dysfunction [135]. Furthermore, intravenous administration of SNP brings on a rapid, sharp drop in arterial pressure and consequent reflex tachycardia [136]. Therefore, tolerance, the formation of $\mathrm{CN}^{-}$, reflex tachycardia, and endothelial dysfunction are all factors that limit the use of these NO donors, in view of their undesirable side-effects.

\subsection{Organic Nitrates}

Organic nitrate NO donors are the oldest class of donors used in cardiovascular medicine $[137,138]$. This group of NO donors includes organic nitrate esters with a nitroxyl $\left(-\mathrm{O}-\mathrm{NO}_{2}\right)$ and can be used as a monotherapy or in combination with other drugs. Glyceryl trinitrate (GTN), isosorbide mononitrate (ISMN), and isosorbide dinitrate (ISDN) are the most frequently prescribed, while pentaerythrityl tetranitrate (PETN) is little recommended because it does not have proven effectiveness [139-142]. The mechanisms involved in the anti-angina effect induced by organic nitrates include reduction in the preload, which is induced by peripheral vasodilation and, in minor extension, by dilation of the epicardial coronary artery and reduction in systemic BP [143]. The effects of organic nitrates on preload and afterload lead to reduced oxygen consumption in the heart, in addition to promoting increased oxygen supply due to dilation of both non- and atherosclerotic coronary arteries [144,145].

GTN and PETN have little oral bioavailability, with approximately $90 \%$ being metabolized by the liver. However, they can be administered intradermally or sublingually. On the other hand, nitrates such as ISMN, ISDN, and nicorandil are bioavailable orally, but with a quick duration of effect $[145,146]$.

GTN is the class prototype and the organic nitrate that has been most widely studied to date [147]. GTN is a prodrug metabolized by mitochondrial aldehyde-dehydrogenase (ALDH-2) that converts GTN into nitrated metabolite (1,2-gylceryl dinitrate) and nitrite $\left(\mathrm{NO}_{2}\right) . \mathrm{NO}$ is a result of $\mathrm{NO}_{2}$ reduction or interaction between the two metabolites [148].

\subsection{Clinical Use and Limitations of Nitric Oxide Donors}

The in vivo effects of organic nitrates are well established and possess some advantages compared to other classes of nitrates [123,148-150]. The therapeutic benefits of nitrates are related to their effects on peripheral and coronary circulation. Clinically, the inhalation of NO has been approved for primary pulmonary hypertension in newborns [151]. In addition, GTN-induced exhaled NO has been shown to be a valuable tool to monitor metabolic function of the pulmonary vasculature, in contrast to endogenous NO in exhaled breath, which could be a marker of the production and consumption of NO in the airways [152]. Recent studies demonstrated that there are remarkable changes in GTNinduced exhaled $\mathrm{NO}$ after cardiopulmonary bypass $(\mathrm{CPB})$. In fact, there was a significant reduction in the increase in exhaled NO induced by GTN at 1 and $3 \mathrm{~h}$ after CPB [153]. Thus, this finding indicates that, although NO production/consumption in the airway 
compartment may remain intact after cardiac surgery, consumption reaction may dominate in the microvascular compartment [154].

Another use of NO donors is in chemo- and radiotherapy. NO donors have a role in enhancing the tumor perfusion to improve tumor therapy [155]. In an interesting clinical trial, transdermal administration with GTN improved the indicators in patients with advanced cell lung cancer [156,157].

When administered by the oral route, organic nitrates present variable oral bioavailability, due to a variable rate of hepatic first-pass metabolism [146,158-160]. It is rapidly absorbed (reaching plasma in a few minutes) and distributed and is also quickly cleared from the plasma $[158,159,161]$. Metabolism may be through non-enzymatic and enzymatic systems [161]. On the other hand, inorganic nitrites/nitrates do not undergo first-pass metabolism, presenting, thus, high bioavailability [162-164].

Organic nitrates are metabolized by different pathways, which are either of an activating or degrading nature. Degrading routes for GTN yield inorganic nitrite and nitrate, and glyceryl-1,3-dinitrate. Degradation is accomplished by glutathione reductase (GR) and glutathione-S-transferase (GST) $[165,166]$. Bioactivation routes lead to NO, S-nitrosothiols, inorganic nitrite, and glyceryl-1,2-dinitrate [167]. For the organic nitrates in general, various pathways are described for organic nitrate bioactivation, such as cytochrome P450 superfamily (liver, but not vascular), deoxyhemoglobin, deoxymyoglobin, and xanthine oxidase, GSH-S-transferase $[166,168,169]$. Activation of mitochondrial aldehyde dehydrogenase (mitALDH) is predominant and this mechanism has a key role in nitrate tolerance [147]. The relative role of each enzymatic GTN biotransformation pathway in a given tissue or specialized cell type may be influenced by factors such as its prevailing abundance, isozyme pattern, and substrate specificity [124]. The major nitros(yl)ation sites for GTN are the heart and liver [124].

The inorganic nitrites/nitrates follow the nitrate-nitrite-NO activation pathway, and may be through heme proteins, deoxymyoglobin, xanthine oxidase, endothelial Nitric Oxide synthase, and aldehyde oxidase, among others [170-175]. Moreover, mammalian commensal bacteria may reduce nitrate to nitrite $[176,177]$.

As elegantly reviewed by Omar and colleagues, 2012 there are some differences in the therapeutic uses of organic and inorganic nitrites/nitrates. While organic nitrates have a negative impact on endothelial function through the production of ROS [177], inorganic nitrites/nitrates present a positive impact. Both induce a fall in SBP, but the fall induced by organic nitrites/nitrates present rapid onset, while inorganic is slower. The use of organic nitrates is highly limited by the induction of tolerance, while there is no evidence of tolerance for inorganic nitrates. Both organic and inorganic nitrates lead to a reduction in pulmonary arterial pressure when inhaled [145].

A number of adverse effects of the organic nitrates are known. The acute effects, such as hypotension, dizziness, nausea, and headache, are associated with the vasodilator effect [145]. The notable effects associated with chronic use are nitrate tolerance, increased oxidative stress, and endothelial dysfunction $[145,165]$. Inorganic nitrites/nitrates may also induce the acute effects of reflex tachycardia [136], but, differently, there is no evidence of tolerance for inorganic nitrites/nitrates [178]. In addition, a carcinogenic effect in rodents has been observed with the use of certain nitrosamines [179].

It is already known that these compounds can be used to treat cardiovascular diseases, such as acute myocardial infarction, and hypertensive emergencies, due to their vasorelaxant properties $[167,180]$. However, long-term administration of organic nitrates has been shown to diminish their hemodynamic effects [181]. Long-term treatment with GTN causes tolerance and consequent loss of the hemodynamic effect [182] and also induces endothelial dysfunction [167]. In addition, clinical trials have demonstrated contradictory effects regarding their use in atherothrombotic diseases, especially with long-term nitrate use [183].

A mechanism which leads to nitrate tolerance involves increasing levels of endothelin within the vasculature, activation of PLC and protein kinase C (PKC), and a subsequent increase in actomyosin activity and myocyte contractility. Moreover, activation of the RhoA/Rho 
kinase pathway contributes to vasoconstriction by inhibition of MLCP [180,184,185]. In addition, continuous treatment with GTN induces NOS dysfunction, probably by reduction in $\mathrm{BH}_{4}$ bioavailability [186].

Tolerance induced by nitrates can also comprise the desensitization of sGC, resulting in decreased responsiveness to NO $[184,187]$. Furthermore, a remarkable study revealed that GTN metabolism induces ROS production following oxidation of thiol groups in the active site of ALDH-2, which may cause inhibition of ALDH-2 enzyme activity and reduce GTN efficacy $[141,188]$. In addition, another type of tolerance, called pseudo-tolerance, which is characterized by dysfunction in neurohormonal systems such as elevated catecholamine release rates and circulating catecholamine levels, sodium retention, and intravascular volume expansion, however this phenomenon is induced in response to every vasodilator therapy $[141,189]$.

Differently from other organic nitrates, PETN does not induce tolerance in animals or humans [190,191], probably because it does not induce an increase in vascular production of ROS, as seen with GTN [192,193], and did not change ALDH-2 activity [194].

It has been shown that PETN therapy improves pulmonary hypertension beyond its known cardiac preload reducing ability [195] and may be beneficial in the treatment of ischemic heart diseases involving oxidative stress and impairment in nitric oxide bioactivity [196]. Furthermore, PETN induced a reduction in BP in SHR female but not male offspring of mothers fed with a high-fat diet. It also diminished ACE expression, profibrotic cytokines, and kidney fibrosis, suggesting epigenetic changes [197,198].

In a model of superimposed preeclampsia and high-fat diet, maternal PETN treatment showed both beneficial (improved glucose tolerance) and unfavorable effects (increase in blood pressure and decrease in EDHF-mediated vasodilation in the offspring) [199].

Molsidomine belongs to the group of sydnonimines. It is metabolized in the liver to SIN-1, which does not require enzymatic bioactivation, so NO is released spontaneously in the arterial wall $[200,201]$. In rats, it has been seen that the administration of molsidomine did not improve pathological changes in the cardiovascular system in SHR [202], but in rats with renal mass reduction, it normalized systemic blood pressure and partially ameliorated renal disease progression, with these effects being potentiated by lisinopril [203]. In combination with other drugs, molsidomine decreased cardiac fibrosis and stabilized systolic function in a model of chronic renocardiac syndrome [204]. Moreover, it attenuated the hypoxia-related effects that lead to pulmonary hypertension [205]. Perinatal administration of molsidomine increased renal vascular resistance and ameliorated hypertension and glomerular injury in adult fawn-hooded hypertensive rats, a model of mild hypertension, impaired preglomerular resistance, and progressive renal injury [206].

In humans, it has been observed that treatment with linsidomine and molsidomine was associated with modest improvement in the long-term angiographic result after angioplasty, although it had no effect on clinical outcome [207]. It also improved flow-mediated vasodilation in patients with artery disease [208], and induced antianginal effects and a decrease in the levels of ICAM-1, which is correlated with the severity of atherosclerosis [209], suggesting an important role in this pathology.

Substantial evidence has shown that NO is involved in many inflammatory conditions. Studies have demonstrated that NO can be pro-inflammatory or anti-inflammatory. Due to the dual effects promoted by NO, this phenomenon is often referred to as the NO paradox [210].

The production of $\mathrm{ONOO}^{-}$is a potent oxidant agent that can deeply impair the regular functions of biological systems such as endothelial integrity. In spite of the short half-life of this oxidant at physiological $\mathrm{pH}$, the interaction of $\mathrm{ONOO}^{-}$with the cellular membrane and molecules with biological activity provokes damaging outcomes in pathophysiological oxidative-stress conditions [211], which include inhibition, inactivation, or activation of enzymes, modification in protein structure, and disorders in signaling pathways and cellular energetic disbalance [212]. Studies have verified that $\mathrm{ONOO}^{-}$induces activation of COX-1 and COX-2 enzymes with subsequent production of prostaglandins [213]. Neverthe- 
less, $\mathrm{ONOO}^{-}$could also inhibit COX activity mediated by nitration of tyrosin385 residue, producing a divergent response in regard to prostanoid formation [214,215].

There are differences in the ways in which NO is released, the amount of NO generated, and the time during which it is released from the NO donors mentioned above. S-nitrosoGlutathione (GSNO) is found in vivo and is an important intermediary in organic nitrate metabolism. The remaining nitrosothiols are synthetic. These compounds act as intermediates in the nitrosylation of proteins and possess the ability to transfer the different NO species through chains of thiols, without releasing the NO molecule itself. This action mitigates the probability of $\mathrm{NO}$ reacting with $\mathrm{O}_{2}{ }^{\bullet-}$, generating $\mathrm{ONOO}^{-}$, or reacting with other molecules to nitrosylate them [216]. Sydnonimines release NO spontaneously, without enzymatic participation. $\mathrm{O}_{2}{ }^{\bullet-}$ is generated concomitantly and together with $\mathrm{NO}$ leads to ONOO - formation. This reaction causes production of hydroxyl radical, increasing its prooxidant potential [217]. SNP does not release NO spontaneously in vitro, but requires partial reduction (one-electron transfer) by a variety of reducing agents shown in membrane cells. In addition to NO, SNP can release, in aqueous solution, a range of oxidant and free radical species, such as iron, cyanide, superoxide, $\mathrm{H}_{2} \mathrm{O}_{2}$, and hydroxyl radical [218-221].

$\mathrm{NO}$ also acts as an anti-inflammatory through the impairment of monocyte adhesion, as well as the expression of proinflammatory target genes of NF- $\mathrm{kB}$, such as TNF- $\alpha$, IL-6, iNOS, ICAM, V-CAM, and COX-2 in vessels as well as in glial cells [222-226]. However, the trigger for these signaling pathways is based on cell type, concentration of NO donor (in vitro studies), administration route, and cell-redox state [221]. For this reason, the conclusion is that $\mathrm{NO}$ cannot be rigidly classified as either an anti-inflammatory or a pro-inflammatory gas [210].

Despite the potential of NO in medicine, only two types of NO donor drugs, SNP and organic nitrates, are currently used in the clinic [127]. Other classes of NO donors are available for clinical studies, such as the derivatives of a minor heterocycle system, the furoxan ring. 4-Methyl-3-phenylsulfonylfuroxan is one of the most active products of the furoxans. Its ability to inhibit platelet aggregation induced by arachidonic acid in human plasma is reversed by the presence of $\mathrm{HbO}_{2}{ }^{++}$, a well-known scavenger of $\mathrm{NO}$. Furthermore, it increases cGMP levels in human platelets in a dose-dependent manner and inhibits the increase in $\mathrm{Ca}^{2+}$ concentration induced by arachidonic acid [227].

New chemical classes of NO donors have now been synthesized and may have potential for the treatment of CVDs. Our research group and others have studied some new NO donors which induced hypotension in normotensive rats such as (Z)-ethyl 12- nitrooxyoctadec-9-enoate (NCOE) [126] and cis-[Ru(bpy) $\left.)_{2}(\mathrm{py})\left(\mathrm{NO}_{2}\right)\right]\left(\mathrm{PF}_{6}\right)(\mathrm{RuBPY})$ [125] as well as in hypertensive animals, for instance 2-nitrate-1,3-dibuthoxypropan (NDBP) [228-230], the nitrosyl-ruthenium complex [Ru(terpy)(bdq) $\left.\mathrm{NO}^{+}\right] 3^{+}$(TERPY) [231-234], the cyclohexane nitrate (HEX) [235], and the organic nitrate 1,3-bis (hexyloxy) propan-2-yl nitrate (NDHP) [236] (Table 1).

Table 1. Classic NO donors.

\begin{tabular}{|c|c|c|c|c|}
\hline No Donor & Class & Clinical Uses & Clinical Limitations & References \\
\hline $\begin{array}{l}\text { Sodium } \\
\text { Nitroprusside } \\
\text { (SNP) }\end{array}$ & $\begin{array}{c}\text { Inorganic } \\
\text { donor }\end{array}$ & $\begin{array}{l}\text {-Vasodilation in hypertensive } \\
\text { crisis and cardiovascular } \\
\text { emergencies, such as angina } \\
\text { pectoris and heart failure } \\
\text {-Hypotensive control during } \\
\text { surgery }\end{array}$ & $\begin{array}{l}\text {-Formation of } \mathrm{CN}^{-} \\
\text {-Reflex tachycardia } \\
\text {-Endothelial dysfunction } \\
\text {-Tolerance }\end{array}$ & {$[38,123,131-136]$} \\
\hline Molsidomine & Sydnonimines & $\begin{array}{l}\text {-Vasodilation in patients with } \\
\text { artery disease } \\
\text {-Antianginal effects }\end{array}$ & $\begin{array}{l}\text {-Despite an improvement in } \\
\text { the long-term angiographic } \\
\text { result after angioplasty, it } \\
\text { induced no effect on clinical } \\
\text { outcome }\end{array}$ & {$[200,202,207,209]$} \\
\hline
\end{tabular}


Table 1. Cont.

\begin{tabular}{|c|c|c|c|c|}
\hline No Donor & Class & Clinical Uses & Clinical Limitations & References \\
\hline $\begin{array}{l}\text { Glyceryl } \\
\text { trinitrate }(\mathrm{GTN})\end{array}$ & $\begin{array}{l}\text { Organic } \\
\text { nitrate }\end{array}$ & $\begin{array}{l}\text {-Antianginal effect (reduction in } \\
\text { the preload by peripheral } \\
\text { vasodilation and dilation of the } \\
\text { epicardial coronary artery) and } \\
\text { reduction in systemic BP } \\
\text {-Increase in oxygen supply due to } \\
\text { dilation of both non- and } \\
\text { atherosclerotic coronary arteries }\end{array}$ & $\begin{array}{l}\text {-Small oral bioavailability } \\
\text {-Endothelial dysfunction } \\
\text {-Tolerance } \\
\text {-Increases oxidative stress } \\
\text {-Increases autocrine endothelin } \\
\text { expression } \\
\text {-Induces supersensitivity to } \\
\text { vasoconstrictors }\end{array}$ & [143-146,167,181-183] \\
\hline $\begin{array}{l}\text { Isosorbide } \\
\text { mononitrate } \\
\text { (ISMN) }\end{array}$ & $\begin{array}{l}\text { Organic } \\
\text { nitrate }\end{array}$ & $\begin{array}{l}\text {-Vasodilation for the treatment of } \\
\text { angina pectoris } \\
\text {-Vasodilation of coronary arteries }\end{array}$ & $\begin{array}{l}\text {-Short effect, despite the oral } \\
\text { bioavailability } \\
\text {-Endothelial dysfunction } \\
\text {-Therapy of post-infarct leads } \\
\text { to an increased rate of } \\
\text { coronary events } \\
\text {-Increases oxidative stress } \\
\text {-Increases autocrine endothelin } \\
\text { expression; } \\
\text {-Supersensitivity to } \\
\text { vasoconstrictors }\end{array}$ & [143-146] \\
\hline $\begin{array}{c}\text { Isosorbide } \\
\text { dinitrate (ISDN) }\end{array}$ & $\begin{array}{l}\text { Organic } \\
\text { nitrate }\end{array}$ & $\begin{array}{l}\text {-Vasodilation for the treatment of } \\
\text { angina pectoris } \\
\text {-Vasodilation of coronary arteries }\end{array}$ & $\begin{array}{l}\text {-Short effect, despite the oral } \\
\text { bioavailability }\end{array}$ & {$[143,145,146]$} \\
\hline $\begin{array}{l}\text { Pentaerythrityl } \\
\text { tetranitrate } \\
(\text { PETN })\end{array}$ & $\begin{array}{l}\text { Organic } \\
\text { nitrate }\end{array}$ & $\begin{array}{l}\text {-Improvement in pulmonary } \\
\text { hypertension beyond reduction in } \\
\text { the preload } \\
\text {-Treatment of ischemic heart } \\
\text { diseases } \\
\text {-Does not induce tolerance }\end{array}$ & -Little oral bioavailability & [143-146,195] \\
\hline Nicorandil & & $\begin{array}{l}\text {-Vasodilation for chronic stable } \\
\text { angina }\end{array}$ & $\begin{array}{l}\text {-Short effect, despite the oral } \\
\text { bioavailability }\end{array}$ & [142-146] \\
\hline
\end{tabular}

\subsection{Metal-Based Drugs as NO Donors}

Stretching back 5000 years, compounds containing metal ions have been widely used to treat various diseases [237]. As many of these compounds contain a metal in their structure and possess pharmacological properties, they are known as metal-based drugs [238].

Recently, metal-based drugs such as ruthenium compounds have been studied as NO donors and are attracting increasing interest, particularly due to their stable active forms under physiological conditions and low toxicity, thereby making them suitable for clinical use [233]. This class could provide a new source of NO-releasing agents in biological targets, especially for relaxation of VSMC.

The use of metals for the development or modification of pharmaceutical products has numerous advantages, including a variable number of geometries and forms of coordination, accessibility to different redox states, and specific thermodynamic and kinetic characteristics, in addition to the intrinsic properties of metal cations and their ligands, which sometimes undergo significant alterations when a metal complex is formed [239-241].

The biological properties of ruthenium complexes were first reported in the 1950s [242], and prospection of nitrosyl compounds with transition metals has raised the prospect of the formation of NO-releasing agents and, in particular, redox release of $\mathrm{NO}$ in biological targets. Drugs capable of activating the intracellular receptor of NO, sGC, independently of endothelial $\mathrm{NO}$ have been developed to address the issue of tolerance produced by nitrates.

In view of the promotion of such actions by $\mathrm{NO}$ and the side-effects of $\mathrm{NO}$ donor drugs, such as nitrate-tolerance in clinical settings, some research groups, including ours, have been studying metal-based NO donor drugs that act on the cardiovascular system, 
with a potential action to induce vasorelaxant activity and BP and decrease oxidative stress, among other effects [45,243-248].

The trans- $\left[\mathrm{Ru}(\mathrm{Cl}) \mathrm{NO}(\mathrm{cyclam})^{2+}\right.$ complex has been shown to sustain a more prolonged hypotensive effect, averaging $15 \mathrm{~min}$, which is almost 20 times the duration of the effects of SNP, in either normotensive or hypertensive mice [249]. Another study using a ruthenium complex demonstrated that trans- $\left[\mathrm{RuCl}\left([15] \mathrm{aneN}_{4}\right) \mathrm{NO}\right]^{2+}$ induced rat aorta dilatation only in the presence of a reducing agent by the sGC-cGMP pathway and potassium-channel activation, which leads to a decrease in cytoplasmic $\mathrm{Ca}^{2+}$ concentration. This compound releases $\mathrm{NO} \cdot$ and $\mathrm{NO}^{-}$species $[243,244]$.

A ruthenium compound that has been extensively studied, called TERPY, also induced aorta relaxation through sGC-cGMP and potassium-channel pathways, but not sarcoplasmic reticulum $\mathrm{Ca}^{2+}$-ATPase activation [245]. Interestingly, TERPY failed to induce vascular relaxation in rat basilar arteries, probably due to impairment in enzymatic bioactivation of the NO donor in this vascular bed [246]. This should be pointed out as an important characteristic as cerebral vasodilation is believed to be the major reason for NO donorinduced headaches [250]. On the other hand, the relaxation induced by TERPY was similar in mesenteric resistance arteries from Sham and two-kidney-one-clip hypertensive rats (2K1C), but not in aorta, probably due to impairment in the potassium-channel activation induced by TERPY in this last vessel [251,252]. Furthermore, although less potent than SNP, TERPY induced a long-lasting effect which was greater in 2K1C than in normotensive rats. This long-lasting effect could be related to the slow release of $\mathrm{NO}$, which could be an interesting characteristic of TERPY as a potential therapeutic vasodilator [232]. In aortas from spontaneously hypertensive rats (SHR), the relaxation induced by TERPY was not different from Wistar control rats, and neither was the amount of NO released by the compound [233]. Moreover, the effect of TERPY was improved by the presence of endothelium and eNOS in SHR, through uncoupling and hyperphosphorylation of eNOS [253]. Additionally, the hypotensive effect of TERPY was greater in male than in female SHR, probably due to oxidative stress [254].

Another metal-based drug complexed with ruthenium, RuBPY, which has a nitrite instead of NO in its moiety, required the presence of the tissue to release NO, showing its stability in solution. The likely enzyme responsible for this release is sGC. RuBPY induced relaxation through the NO-cGC pathway in rat aortas [255]. However, in cultured VCMC from rat aorta, RuBPY was able to induce NO. release that activates $\mathrm{K}^{+}$channels in an sGC-independent pathway [256]. On the other hand, RuBPY induced relaxation in rat mesenteric resistance arteries through NO-sGC-cGMP-PKG-pathway activation, but not through $\mathrm{K}^{+}$channels or SERCA triggering [42].

Concerning hypertensive animals, Pereira et al. (2017) investigated the effect of RuBPY in different arteries in $2 \mathrm{~K} 1 \mathrm{C}$ rats. The authors observed that the relaxation was similar in aorta, mesenteric resistance, and coronary arteries between normotensive and $2 \mathrm{~K} 1 \mathrm{C}$ rats, although it was smaller in basilar arteries from 2K1C than in normotensive rats. Moreover, differently from SNP and similar to TERPY, RuBPY did not induce a hypotensive effect in normotensive rats. Altogether, these data may indicate advantages of RuBPY over SNP, since it does not induce an effect in normotensive rats, while it did induce coronary artery relaxation (which may be useful for angina) and a minor effect in the basilar artery (which may indicate that it does not induce headache) [125]. Furthermore, differently from GTN, RuBPY did not induce self-tolerance or cross-tolerance with acetylcholine, which could be another advantage of this NO donor for clinical use [257].

Importantly, the $\mathrm{NO}$ donors may have distinct characteristics. $\mathrm{Ru}(\mathrm{NO})\left(\right.$ salenCO$\left._{2} \mathrm{H}\right) \mathrm{Cl}$ was able to induce vascular relaxation of rat aorta only in the presence of light, possibly due to photolabilization from the ruthenium nitrosyl [258]. Oishi et al. (2015) have suggested that cis-[Ru(H-dcbpy- $\left.)_{2}(\mathrm{Cl})(\mathrm{NO})\right](\mathrm{DCBPY})$ at low concentration $(0.1 \mu \mathrm{M})$ is not an NO generator, but can inactivate ROS and improve endothelial function [259].

Based on promising compounds studied by us and other Brazilian colleagues, our collaborators have synthetized new metal-based drugs containing the NO molecule to 
induce potential beneficial effects in the cardiovascular system. Many preclinical studies have been performed to support this concept. An NO donor similar to RuBPY, called Rutbpy $\left(\mathrm{Cis}-\left[\mathrm{Ru}(\mathrm{bpy})_{2}\left(\mathrm{SO}_{3}\right)(\mathrm{NO})\right] \mathrm{PF}_{6}\right)$ induced stabilization in $\mathrm{BP}$ in anesthetized hypotensive Wistar rats [260]. Cerqueira et al. (2008) studied two related nitrosyl-ruthenium complexes, named cis- $\left[\mathrm{Ru}(\mathrm{bpy})_{2}\left(\mathrm{SO}_{3}\right)(\mathrm{NO})\right] \mathrm{PF}-6-9$ (FONO1) and trans-[Ru( $\left.\mathrm{NH}_{3}\right) 4$ (caffeine)(NO)]C1 $1_{3}$ (LLNO1), which demonstrated a potent vasodilator effect in rabbit corpus cavernosum [261], corroborating the vasodilator potential of these drugs.

Recently, new nitrosyl-ruthenium compounds, denominated FOR, have been produced from a simple and easy route and tested in the cardiovascular system and other organic systems, demonstrating remarkable outcomes. The cis-[Ru(bpy $\left.)_{2}(2-\mathrm{MIM})(\mathrm{NO})\right]\left(\mathrm{PF}_{6}\right)_{3}$ (FOR811A) was studied in a murine model of allergic asthma and it decreased the alveolar collapse and preserved the bronchoconstriction during asthma. In addition, molecular docking using FOR811A showed a strong interaction with the heme group of cGC [262]. Another compound, cis-[Ru( $\left.\left(\mathrm{NO}_{2}\right)(\mathrm{bpy})_{2}(5 \mathrm{NIM})\right] \mathrm{PF}_{6}$ complex showed a potential pharmacological application as an antioxidant and anti- inflammatory (inhibition of pro-inflammatory cytokines) in in vitro studies [263].

Finally, a very recent study demonstrated that the new ruthenium-based nitric oxide donor cis-[Ru(bpy $\left.)_{2}(\mathrm{ImN})(\mathrm{NO})\right]^{3+}$ (FOR0811) administered intravenously by bolus infusion or chronically using subcutaneous implanted osmotic pumps, decreased BP, presenting a long-lasting effect, and did not demonstrate reflex tachycardia in $\mathrm{L}-\mathrm{N}^{\mathrm{G}}$-Nitro arginine methyl ester (L-NAME) hypertensive rats [248]. In addition, FOR0811 induced a reduction in the low (LF) and very low (VLF) frequency bands. The authors also detected a vasorelaxant response in aortic rings mediated by the sGC-cGMP pathway after addition of FOR0811 [248]. Furthermore, FOR0811 evoked relaxation in human corpus cavernosum and was able to increase cGMP levels, and this effect was either blocked or reversed by a cGC inhibitor, the 1-H-[1,2,4] oxadiazolo-[4,3-a]quinoxaline-1-one (ODQ) [264]. These responses elicit the new ruthenium complex as a promising NO donor to treat cardiovascular dysfunctions. At this moment our research group is concentrating on the study of metalbased drugs similar to FOR0811 (unpublished data). Notable results on vascular activity and BP have been revealed, encouraging us to continue the study of these compounds with a future perspective to their use in humans (Table 2).

Table 2. New chemical classes of NO donors.

\begin{tabular}{|c|c|c|c|c|c|}
\hline No Donor & Class & Effect & Species & Tolerance & References \\
\hline $\begin{array}{l}\text { (Z)-ethyl } \\
\text { 12-nitrooxy-octadec-9-enoate } \\
\text { (NCOE) }\end{array}$ & Organic nitrate & $\begin{array}{l}\text {-Short-lasting hypotension } \\
\text { and bradycardia } \\
\text {-Vasorelaxation }\end{array}$ & Rat & $\begin{array}{l}\text { Does not cause } \\
\text { in vitro } \\
\text { tolerance }\end{array}$ & [126] \\
\hline $\begin{array}{l}\text { 2-nitrate-1,3-dibuthoxypropan } \\
\text { (NDBP) }\end{array}$ & Organic nitrate & $\begin{array}{l}\text {-Hypotension, bradycardia, } \\
\text { and bradypnea } \\
\text {-Prevention of the } \\
\text { progression of angiotensin } \\
\text { II-mediated hypertension }\end{array}$ & Rat & $\begin{array}{l}\text { Does not cause } \\
\text { in vitro } \\
\text { tolerance }\end{array}$ & {$[228,229,231]$} \\
\hline Cyclohexane Nitrate (HEX) & Organic nitrate & $\begin{array}{l}\text {-Reduction in blood } \\
\text { pressure and heart rate } \\
\text {-Antihypertensive effect in } \\
\text { renovascular hypertension } \\
\text {-Vasorelaxation in cranial } \\
\text { artery }\end{array}$ & Rat & - & [235] \\
\hline $\begin{array}{l}\text { 1,3-bis (hexyloxy) propan-2-yl } \\
\text { nitrate (NDHP) }\end{array}$ & Organic nitrate & $\begin{array}{l}\text { - Reduction in blood } \\
\text { pressure in hypertensive } \\
\text { animals } \\
\text {-Vasorelaxation } \\
\text {-Prevention of the } \\
\text { progression of } \\
\text { hypertension and } \\
\text { endothelial dysfunction }\end{array}$ & Rat & $\begin{array}{l}\text { Does not cause } \\
\text { in vitro } \\
\text { tolerance }\end{array}$ & [236] \\
\hline
\end{tabular}


Table 2. Cont

\begin{tabular}{|c|c|c|c|c|c|}
\hline No Donor & Class & Effect & Species & Tolerance & References \\
\hline $\begin{array}{l}{\left[\mathrm{Ru}(\text { terpy })(\mathrm{bdq}) \mathrm{NO}^{+}\right]^{3+}} \\
(\mathrm{TERPY})\end{array}$ & Metal-based drugs & $\begin{array}{l}\text {-Vasorelaxation in aorta } \\
\text { and mesenteric resistance } \\
\text { arteries from Sham and } \\
\text { two-kidney-one-clip } \\
\text { hypertensive (2K1C) } \\
\text {-Long-lasting hypotensive } \\
\text { effect in 2K-1C, but not in } \\
\text { normotensive } \\
\text {-Similar vasorelaxation and } \\
\text { released NO in aortas from } \\
\text { Wistar and Spontaneously } \\
\text { Hypertensive Rats (SHR) } \\
\text { - Does not induce } \\
\text { vasorelaxation in basilar } \\
\text { arteries } \\
\text {-Hypotensive effect in SHR }\end{array}$ & Rat & - & $\begin{array}{l}{[231-234,245,} \\
251,252,254]\end{array}$ \\
\hline $\begin{array}{c}{[\mathrm{Ru}(\mathrm{bpy}) 2(\mathrm{py})(\mathrm{NO} 2)](\mathrm{PF} 6)} \\
\text { (RuBPY) }\end{array}$ & Metal-based drugs & $\begin{array}{l}\text {-Induced relaxation in } \\
\text { aorta, mesenteric resistance } \\
\text { arteries; coronary arteries } \\
\text { between normotensive and } \\
\text { 2K1C rats } \\
\text {-Did not induce } \\
\text { hypotensive effect in } \\
\text { normotensive rats } \\
\text {-Induced coronary artery } \\
\text { relaxation (which may be } \\
\text { useful for angina) and a } \\
\text { minor effect in basilar } \\
\text { artery (which may indicate } \\
\text { that it does not induce } \\
\text { headache). } \\
\text {-NO· release that activates } \\
\text { K+ channels in cultured } \\
\text { VCMC aorta }\end{array}$ & Rat & $\begin{array}{l}\text { Does not cause } \\
\text { in vitro } \\
\text { tolerance (self- } \\
\text { or } \\
\text { cross-tolerance) }\end{array}$ & $\begin{array}{l}{[42,125,255-} \\
257]\end{array}$ \\
\hline trans- $\left[\mathrm{Ru}(\mathrm{Cl}) \mathrm{NO}(\text { cyclam })^{2+}\right.$ & Metal-based drugs & $\begin{array}{l}\text {-Long-lasting hypotensive } \\
\text { effect ( } 20 \text { times greater than } \\
\text { SNP) in normotensive and } \\
\text { hypertensive animals }\end{array}$ & Mouse & - & [249] \\
\hline trans-[RuCl([15]aneN4)NO] $]^{2+}$ & Metal-based drugs & $\begin{array}{l}\text {-Vasorelaxation in aorta } \\
\text { (due to the release of NO. } \\
\text { and NO-species) }\end{array}$ & Rat & - & {$[243,244]$} \\
\hline $\mathrm{Ru}(\mathrm{NO})($ salenCO2H)Cl & Metal-based drugs & -Vasorelaxation in aorta & Rat & - & [258] \\
\hline $\begin{array}{c}\text { Rut-bpy } \\
\text { (Cis-[Ru(bpy)2(SO3)(NO)]PF6 }\end{array}$ & Metal-based drugs & $\begin{array}{l}\text {-Stabilization of BP in } \\
\text { anesthetized hypotensive } \\
\text { animals }\end{array}$ & Rat & - & [260] \\
\hline $\begin{array}{c}\text { cis-[Ru(bpy)2(SO3)(NO)]PF-6-9 } \\
\text { (FONO1) }\end{array}$ & Metal-based drugs & $\begin{array}{l}\text {-Vasodilation in corpus } \\
\text { cavernosum }\end{array}$ & Rabbit & - & [261] \\
\hline $\begin{array}{c}\text { trans- } \\
{[\mathrm{Ru}(\mathrm{NH} 3) 4(\text { caffeine)(NO) }] \mathrm{C} 13} \\
\text { (LLNO1) }\end{array}$ & Metal-based drugs & $\begin{array}{l}\text {-Vasodilation in corpus } \\
\text { cavernosum }\end{array}$ & Rabbit & - & [261] \\
\hline $\begin{array}{l}\text { cis-[Ru(bpy)2(2- } \\
\text { MIM)(NO)](PF6)3 } \\
\text { (FOR811A) }\end{array}$ & Metal-based drugs & $\begin{array}{l}\text {-Decrease in alveolar } \\
\text { collapse and prevention of } \\
\text { bronchoconstriction during } \\
\text { asthma }\end{array}$ & Mouse & - & [262] \\
\hline $\begin{array}{c}\text { cis-[Ru(bpy)2(ImN)(NO) }]^{3+} \\
\text { (FOR0811) }\end{array}$ & Metal-based drugs & $\begin{array}{l}\text {-Decrease in BP } \\
\text { (long-lasting) with no reflex } \\
\text { tachycardia in L-NG-Nitro } \\
\text { arginine methyl ester } \\
\text { (L-NAME) hypertensive } \\
\text { rats } \\
\text {-Reduction in the low (LF) } \\
\text { and very low (VLF) } \\
\text { frequency bands in rats } \\
\text {-Vasorelaxation in rat aorta } \\
\text {-Vasorelaxation of human } \\
\text { corpus cavernosum }\end{array}$ & $\begin{array}{l}\text { Rat } \\
\text { and } \\
\text { hu- } \\
\text { man }\end{array}$ & - & [248] \\
\hline
\end{tabular}




\section{Conclusions}

In this paper, we briefly reviewed the role of $\mathrm{NO}$ in the cardiovascular system, focusing on its involvement in vasodilation. Based on the important properties of NO, NO donors were produced and have been used for the treatment of vascular disorders. However, due to the side effects presented by these donors, particularly vascular tolerance, new molecules have emerged with the potential to be used in the treatment of cardiovascular diseases. In this context, new organic nitrates such as NDBP, NCOE, and NDHP, and especially metal-based drugs with $\mathrm{NO}$ in their structure, have been studied by our research group and collaborators. Among them, TERPY and RuBPY have been widely explored, which demonstrated robust hypotensive and vasorelaxant responses in several models of hypertension. In addition, we are currently investigating other new ruthenium complexes named FOR. These studies have shown very promising results, which lead us to continue the analyses in an attempt to abolish the harmful effects presented by other NO donors used in clinical practice.

Funding: This research was funded by the Conselho Nacional de Desenvolvimento Científico e Tecnológico (CNPq) grant number [436605/2018-0] to TMQ. This study was also financed by the Federal University of Pernambuco-UFPE and Coordenação de Aperfeiçoamento de Pessoal de Nível Superior-Brazil (CAPES)—Finance Code 001.

Institutional Review Board Statement: Not applicable.

Informed Consent Statement: Not applicable.

Data Availability Statement: Not applicable.

Conflicts of Interest: The authors declare no conflict of interest.

\section{References}

1. Pardali, E.; Dimmerler, S.; Zeiher, M.A.; Rieger, A.M. Clonal hematopoiesis, aging, and cardiovascular diseases. Exp. Hematol. 2020, 83, 95-104. [CrossRef] [PubMed]

2. GBD 2017 Risk Factor Collaborators. Global, regional, and national comparative risk assessment of 84 behavioural, environmental and occupational, and metabolic risks or clusters of risks for 195 countries and territories, 1990-2017: A systematic analysis for the Global Burden of Disease Study 2017. Lancet 2018, 392, 1923-1994.

3. James, A.P.; Oparil, S.; Carter, L.B.; Cushman, C.W.; Dennison-Himmelfarb, C.; Handler, J.; Lackland, T.D.; LeFevre, L.M.; MacKenzie, D.T.; Ogedegbe, O.; et al. Evidence-based guideline for the management of high blood pressure in adults: Report from the panel members appointed to the Eighth Joint National Committee (JNC 8). JAMA 2014, 311, 507-520. [CrossRef]

4. Herringto, W.; Lacey, B.; Sherliker, P.; Armitage, J.; Lewington, S. Epidemiology of Atherosclerosis and the Potential to Reduce the Global Burden of Atherothrombotic Disease. Circ. Res. 2016, 118, 535-546. [CrossRef] [PubMed]

5. Oprail, S.; Schmieder, E.R. New Approaches in the Treatment of Hypertension. Circ. Res. 2015, 116, 1074-1095. [CrossRef] [PubMed]

6. Pintévorá, M.; Kuneš, J.; Zicha, J. Altered neural and vascular mechanisms in hypertension. Physiol. Res. 2011, 60, 381-402.

7. Ledoux, J.; Werner, E.M.; Brayden, E.J.; Nelson, T.M. Calcium-activated potassium channels and the regulation of vascular tone. Physiology 2006, 21, 69-78. [CrossRef] [PubMed]

8. Moncada, S.; Palmer, R.M.; Higgs, E.A. Nitric oxide: Physiology, pathophysiology, and pharmacology. Pharmacol. Rev. 1991, 43, 109-140. [PubMed]

9. Davel, A.P.; Wenceslau, C.F.; Akamine, E.H.; Akamine, E.H.; Xavier, F.E.; Couto, G.K.; Oliveira, H.T.; Rossoni, L.V. Endothelial dysfunction in cardiovascular and endocrine-metabolic diseases: An update. Braz. J. Med. Biol. Res. 2011, 44, 920-932. [CrossRef] [PubMed]

10. Schmidt, M.I.; Duncan, B.B.; Silva, G.A.; Menezes, A.M.; Monteiro, C.M.; Barreto, S.M.; Chor, D.; Menezes, P.R. Doenças crônicas não transmissíveis no Brasil: Carga e desafios atuais. Lancet 2011, 377, 61-74.

11. Rahimi, K.; Emdin, C.A.; MacMahon, S. The epidemiology of blood pressure and its worldwide management. Circ. Res. 2015, 116, 925-936. [CrossRef]

12. Rossier, B.C.; Bochud, M.; Devuyst, O. The Hypertension Pandemic: An Evolutionary Perspective. Physiology 2017, 32, 112-125. [CrossRef]

13. Praxedes, J.N.; Santello, J.L.; Amodeo, C. Encontro multicêntrico sobre crises hipertensivas: Relatório e recomendações. Hipertensão 2001, 4, 23-41. 
14. Unger, T.; Borghi, C.; Charchar, F.; Khan, N.A.; Poulter, N.R.; Prabhakaran, D.; Ramirez, A.; Schlaich, M.; Stergiou, G.S.; Tomaszewski, M.; et al. International Society of Hypertension Global Hypertension Practice Guidelines. Hypertension 2020, 75, 1334-1357. [CrossRef]

15. NCD Risk Factor Collaboration (NCD-RisC). Worldwide trends in blood pressure from 1975 to 2015: A pooled analysis of 1479 population-based measurement studies with 19.1 million participants. Lancet 2017, 389, 37-55. [CrossRef]

16. World Health Organization. Global Status Report on Noncommunicable Diseases 2010; World Health Organization: Geneva, Switzerland, 2011.

17. Ajayi, I.O.; Sowemimo, I.O.; Akpa, O.M.; Ossai, N.E. Prevalence of hypertension and associated factors among residents of Ibadan-North Local Government Area of Nigeria. Niger. J. Cardiol. 2016, 13, 67. [CrossRef]

18. Hasan, M.; Akter, I.S.T.; Gupta, R.J.; Joshi, H.; Haider, M.R.; Sarker, M. Prevalence and determinants of hypertension among adult population in Nepal: Data from Nepal Demographic and Health Survey 2016. PLoS ONE 2018, 13, e0198028. [CrossRef] [PubMed]

19. Olié, V.; Perrine, A.L.; Lecoffre, C.; Blacher, J. National prevalence of hypertension, treatment and control, in France in 2015 and temporal trends since 2006. Arch. Cardiovasc. Dis. Suppl. 2018, 11, 96-103. [CrossRef]

20. Picon, R.V.; Fuchs, F.D.; Moreira, L.B.; Riegel, G.; Fuchs, S.C. Trends in Prevalence of Hypertension in Brazil: A Systematic Review with Meta-Analysis. PLoS ONE 2021, 7, e48255. [CrossRef] [PubMed]

21. Malta, D.C.; Bernal, R.T.I.; Andrade, S.S.C.A.; Silva, M.M.A.; Velasquez-Melendez, G. Prevalência e fatores associados com hipertensão arterial autorreferida em adultos brasileiros. Rev. Saúde Pública 2017, 51,1-11.

22. Tortorella, C.C.S.; Corso, A.C.T.; Gonzáles-Chica, D.A.; Melhen, A.R.F. Time trends of hypertension and diabetes mellitus prevalence among adults registered in the Brazilian National Health System, in Florianópolis, Santa Catarina State, Brazil, 2004-2011. Epidemiol. Serv. Saúde 2017, 26, 469-480. [CrossRef]

23. Whelton, P.K.; Carey, R.M.; Aronow, W.S.; Casey, D.E., Jr.; Collins, K.J.; Himmelfarb, C.D.; DePalma, S.M.; Gidding, S.; Jamerson, K.A.; Jones, D.W.; et al. 2017 ACC/AHA/AAPA/ABC/ACPM/AGS/APhA/ASH/ASPC/NMA/PCNA Guideline for the Prevention, Detection, Evaluation, and Management of High Blood Pressure in Adults: Executive Summary. J. Am. Soc. Hypertens. 2018, 12, 579.e1-579.e73. [CrossRef] [PubMed]

24. Fruhbeck, G. Pivotal role of nitric oxide in the control of blood pressure after leptin administration. Diabetes 1999, 48, 903-908. [CrossRef] [PubMed]

25. Verma, V.; Buchanan, M.R.; Anderson, T.J. Endothelial function testing as a biomarker of vascular disease. Circulation 2003, 108, 2054-2059. [CrossRef]

26. Le Brocq, M.; Leslie, S.J.; Milliken, P.; Megson, I.L. Endothelial Dysfunction: From molecular mechanisms to measurement, clinical implications, and therapeutic opportunities. Antioxid. Redox Signal. 2008, 10, 1631-1674. [CrossRef] [PubMed]

27. Kim, H.Y.; Oh, H.; Li, X. Ethanol extract of seeds of Oenothera odorata induces vasorelaxation via endothelium dependente NO-Cgmp signaling through activation of Akt-Enos-sGC pathaway. J. Ethnopharmacol. 2011, 133, 315-523. [CrossRef] [PubMed]

28. Vanhoutte, P.M.; Feletou, M.; Taddei, S. Endothelium-dependent contractions in hypertension. Br. J. Pharmacol. 2010, 144, 449-458. [CrossRef]

29. Bernatova, I. Endothelial Dysfunction in Experimental Models of Arterial Hypertension: Cause or Consequence? BioMed Res. Int. 2014, 2014, 598271. [CrossRef] [PubMed]

30. Favero, G.; Paganelli, C.; Buffoli, B.; Rodella, L.F.; Rezzani, R. Endothelium and Its Alterations in Cardiovascular Diseases: Life Style Intervention. BioMed Res. Int. 2014, 2014, 801896. [CrossRef]

31. Sun, S.; Yang, F.; Tan, G.; Costanzo, M.; Oughtred, R.; Hirschman, J.; Theesfeld, C.L.; Bansal, P.; Sahni, N.; Yi, S.; et al. An extended set of yeast-based functional assays accurately identifies human disease mutations. Genome Res. 2016, 26, 670-680. [CrossRef] [PubMed]

32. Davignon, J.; Ganz, P. Role of endothelial dysfunction in atherosclerosis. Circulation 2004, 15, 27-32. [CrossRef] [PubMed]

33. Félétou, M.; Köhler, R.; Vanhoutte, P.M. Endothelium-derived vasoactive factors and hypertension: Possible roles in pathogenesis and as treatment targets. Curr. Hypertens. Rep. 2010, 12, 267-275. [CrossRef] [PubMed]

34. Zhang, Z.G.; Chopp, M.; Bailey, F.; Malinski, T. Nitric oxide changes in the rat brain after trasient middle cerebral artery occlusion. J. Neurol. Sci. 1995, 14, 22-27. [CrossRef]

35. Scatena, R.; Bottoni, P.; Pontoglio, A.; Giardina, B. Pharmacological modulation of nitric oxide release: New pharmacological perspectives, potential benefits and risks. Curr. Med. Chem. 2010, 17, 61-73. [CrossRef] [PubMed]

36. Furchgott, R.F.; Zawadzki, J.V. The obligatory role of endothelial cells in the relaxation of arterial smooth muscle by acetylcholine. Nature 1980, 288, 373-376. [CrossRef] [PubMed]

37. Moncada, V.; Higgs, E.A. Prostaglandins in the pathogenesis and prevention of vascular disease. Blood Rev. 1987, 1, 141-145. [CrossRef]

38. Ignarro, L.J.; Napoli, C.; Loscalzo, J. Nitric oxide donors and cardiovascular agents modulating the bioactivity of nitric oxide: An overview. Circ. Res. 2002, 90, 21-28. [CrossRef] [PubMed]

39. Stamler, J.S.; Singel, D.J.; Loscalzo, J. Biochemistry of nitric oxide and its redox-activated forms. Science 1992, $258,1898-1902$. [CrossRef] 
40. Bonaventura, D.; Oliveira, F.S.; Silva, R.S.; Bendhack, L.M. Decreased vasodilation induced by a new nitric oxide donor in two kidney one clip hypertensive rats is due to impaired $\mathrm{k}$ channel activation. Clin. Exp. Pharmacol. Physiol. 2005, 32, 478-481. [CrossRef]

41. Moncada, S.; Higgs, E.A. Molecular mechanisms and therapeutic strategies related to nitric oxide. J. Fed. Am. Soc. Exp. Biol. 1995, 9, 1319-1330. [CrossRef]

42. Tousoulis, D.; Kampoli, A.-M.; Tentolouris, C.; Papageorgiou, N.; Stefanadis, C. The role of nitric oxide on endothelial function. Curr. Vasc. Pharm. 2012, 10, 4-18. [CrossRef] [PubMed]

43. Cyr, A.R.; Huckaby, L.V.; Shiva, S.S.; Zuckerbraun, B.S. Nitric Oxide and Endothelial Dysfunction. Crit. Care Clin. 2020, 36, 307-321. [CrossRef] [PubMed]

44. Alderton, W.K.; Cooper, C.E.; Knowles, R.G. Nitric oxide synthases: Structure, function and inhibition. Biochem. J. 2001, 357, 593-615. [CrossRef] [PubMed]

45. Araújo, A.V.; Andrade, F.A.; Paulo, M.; Paula, T.P.; Potje, S.R.; Pereira, A.C.; Bendhack, L.M. NO donors induce vascular relaxation by different cellular mechanisms in hypertensive and normotensive rats. Nitric Oxide 2019, 86, 12-20. [CrossRef] [PubMed]

46. McCall, T.B.; Boughton-Smith, N.K.; Palmer, R.J.M.; Whittle, B.J.R.; Moncada, S. Synthesis of nitric oxide from L-arginine by neutrophil release and interaction with superoxide anion. Biochem. J. 1989, 261, 293-296. [CrossRef] [PubMed]

47. Fukuto, J.M.; Chaudhuri, G. Inhibition of constitutive and inducible nitric oxide synthase: Potencial selective inhibition. Annu. Rev. Pharm. Toxicol. 1995, 35, 165-194. [CrossRef] [PubMed]

48. Di Rosa, M.; Giroud, J.P.; Willoughby, D.A. Studies of the mediators of the acute inflammatory response induced in rats in different sites by carrageenan and turpentine. J. Pathol. 1996, 104, 15-29. [CrossRef] [PubMed]

49. Evans, C.H.; Watkins, S.C.; Stefanovic-Racic, M. Nitric oxide and cartilage metabolism. Methods Enzymol. 1996, 269, 75-88. [PubMed]

50. Bredt, D.S.; Snyder, S.H. Isolation of nitric oxide synthetase, a calmodulin-requiring enzyme. Proc. Natl. Acad. Sci. USA 1990, 87, 682-685. [CrossRef]

51. Schmidt, H.H.H.W.; Murad, F. Purification and characterization of human NOS. Biochem. Biophys. Res. Commun. 1991, 181, 1372-1377. [CrossRef]

52. Pollock, J.S.; Forstermann, V.; Mitchell, J.A.; Warner, T.D.; Schmidt, H.H.; Nakane, M.; Murad, F. Purification and characterization of particulate endothelium-derived relaxing factor synthase from cultured and native bovine aortic endothelial cells. Proc. Natl. Acad. Sci. USA 1991, 88, 10480-10484. [CrossRef] [PubMed]

53. Kirkeboen, K.A.; Strand, O.A. The role of nitric oxide in sepsis: An overview. Acta Anaesthesiol. Scand. 1999, 43, $275-288$. [CrossRef] [PubMed]

54. Hunter, R.P. Nitric oxide, inducible nitric oxide synthase and inflammation in veterinary medicine. Anim. Health Res. Rev. 2002, 3, 119-133. [CrossRef] [PubMed]

55. Li, H.; Förstermann, U. Nitric oxide in the pathogenesis of vascular disease. J. Pathol. 2000, 190, 244-254. [CrossRef]

56. Li, H.; Poulos, T.L. Structure-functions studies on nitric oxide synthases. J. Inorg. Biochem. 2005, 99, 293-305. [CrossRef]

57. Hemmens, B.; Goessler, W.; Schmidt, K.; Mayer, B. Role of bound zinc in dimer stabilization but not enzyme activity of neuronal nitric-oxide synthase. J. Biol. Chem. 2000, 275, 35786-35791. [CrossRef]

58. Wever, R.M.; Van Dam, T.; Van Rijn, H.J.M.; Groot, F.; Rabelink, T.J. Tetrahydrobiopterin regulates superoxide and nitric oxide generation by recombinant endothelial nitric oxide synthase. Biochem. Biophys. Res. Commun. 1997, 237, 340-344. [CrossRef] [PubMed]

59. Chalupsky, K.; Cai, H. Endothelial dihydrofolate reductase: Critical for nitric oxide bioavailability and role in angiotensin II uncoupling of endothelial nitric oxide synthase. Proc. Natl Acad. Sci. USA 2005, 102, 9056-9061. [CrossRef]

60. Siu, K.L.; Lotz, C.; Ping, P.; Cai, H. Netrin-1 abrogates ischemia/reperfusion-induced cardiac mitochondrial dysfunction via nitric oxide-dependent attenuation of NOX4 activation and recoupling of NOS. J. Mol. Cell. Cardiol. 2015, 78, 174-185. [CrossRef]

61. Zhang, Y.; Murugesan, P.; Huang, K.; Cai, H. NADPH oxidases and oxidase crosstalk in cardiovascular diseases: Novel therapeutic targets. Nat. Rev. Cardiol. 2020, 17, 170-194. [CrossRef]

62. Rubbo, H.; Radi, R.; Trujillo, M.; Telleri, R.; Kalyanaraman, B.; Barnes, S.; Kirk, M.; Freeman, B.A. Nitric oxide regulation of superoxide and peroxynitrite-dependent lipid peroxidation. Formation of novel nitrogen-containing oxidized lipid derivatives. J. Biol. Chem. 1994, 269, 26066-26075. [CrossRef]

63. Fleming, I.; Busse, R. Molecular mechanisms involved in the regulation of the endothelial nitric oxide synthase. Am. J. Physiol. Regul. Integr. Comp. Physiol. 2003, 284, 1-12. [CrossRef] [PubMed]

64. Garcia-Cardena, G.; Oh, P.; Liu, J.; Schnitzer, J.E.; Sessa, W.C. Targeting of nitric oxide synthase to endothelial cell caveolae via palmitoylation: Implications for nitric oxide signaling. Proc. Natl. Acad. Sci. USA 1996, 93, 6448-6453. [CrossRef] [PubMed]

65. Cho, H.J.; Xie, Q.W.; Calaycay, J.; Mumford, R.A.; Swiderek, K.M.; Lee, T.D.; Nathan, C. Calmodulin is a subunit of nitric oxide synthase from macrophages. J. Exp. Med. 1992, 176, 599-604. [CrossRef]

66. Nathan, C.; Xie, Q.W. Nitric oxide synthases: Roles, tolls, and controls. Cell 1994, 78, 915-918. [CrossRef]

67. Xie, Q.W.; Cho, H.J.; Calaycay, J.; Mumford, R.A.; Swiderek, K.M.; Lee, T.D.; Ding, A.; Troso, T.; Nathan, C. Cloning and characterization of inducible nitric oxide synthase from mouse macrophages. Science 1992, 256, 225-228. [CrossRef] 
68. Xi, L.; Jarrett, N.C.; Hess, M.L.; Kukreja, R.C. Essential role of inducible nitric oxide synthase in monophosphoryl lipid A-induced late cardioprotection: Evidence from pharmacological inhibition and gene knockout mice. Circulation 1999, 99, $2157-2163$. [CrossRef]

69. Kuhl, S.J.; Rosen, H. Nitric oxide and septic shock-from bench to bedside. West. J. Med. 1998, 168, 176-181.

70. Nathan, C. Nitric oxide as a secretory product of mammalian cells. FASEB J. 1992, 6, 3051-3064. [CrossRef] [PubMed]

71. Salerno, J.C.; Harris, D.E.; Irizarry, K.; Patel, B.; Morales, A.J.; Smith, S.M.; Martasek, P.; Roman, L.J.; Masters, B.S.; Jones, C.L.; et al. An autoinhibitory control element defines calcium-regulated isoforms of nitric oxide synthase. J. Biol. Chem. 1997, 272, 29769-29777. [CrossRef]

72. Förstermann, U.; Sessa, W.C. Nitric oxide synthases: Regulation and function. Eur. Heart J. 2012, 7, 829-837. [CrossRef] [PubMed]

73. Geller, D.A.; Nussler, A.K.; Di Silvoi, M.; Lowenstein, C.J.; Shapiro, R.A.; Wang, S.C.; Simmons, R.L.; Billiar, T.R. Cytokines, endotoxin, and glucocorticoids regulate the expression of inducible nitric oxide synthase in hepatocytes. Proc. Natl. Acad. Sci. USA 1993, 90, 522-526. [CrossRef] [PubMed]

74. Spink, J.; Cohen, J.; Evans, J.T.L. The cytokine responsive vascular smooth muscle cell enhancer of inducible nitric oxide synthases activation by nuclear factor-kappa B. J. Biol. Chem. 1995, 270, 29541-29547. [CrossRef] [PubMed]

75. Kobzik, L.; Bredt, D.S.; Lowenstein, C.J.; Drazen, J.; Gaston, B.; Sugarbaker, D.; Stamler, J.S. Nitric oxide synthase in human and rat lung: Immunocytochemical and histochemical localization. Am. J. Respir. Cell Mol. Biol. 1993, 9, 371-377. [CrossRef]

76. Webb, R.C. Smooth muscle contraction and relaxation. Adv. Physiol Educ. 2003, 27, 201-206. [CrossRef]

77. Blatter, L.A. Tissue Specificity: SOCE: Implications for $\mathrm{Ca}^{2+}$ Handling in Endothelial Cells. Adv. Exp. Med. Biol. 2017, 993, 343-361. [PubMed]

78. Ford, P.C.; Lorkovic, I.M. Mechanistic aspects of the reactions of nitric oxide with transition-metal complexes. Chem. Rev. 2002, 102, 993-1018. [CrossRef]

79. Krishnan, S.M.; Kraehling, J.R.; Eitner, F.; Bénardeau, A.; Sandner, P. The Impact of the Nitric Oxide (NO)/Soluble Guanylyl Cyclase (sGC) Signaling Cascade on Kidney Health and Disease: A Preclinical Perspective. Int. J. Mol. Sci. 2018, $19,1712$. [CrossRef]

80. Friebe, A.; Koesling, D. The function of NO-sensitive guanylyl cyclase: What we can learn from genetic mouse models. Nitric Oxide 2009, 21, 149-156. [CrossRef]

81. Kots, A.Y.; Martin, E.; Sharina, I.G.; Murad, F. A short history of cGMP, guanylyl cyclases, and cGMP-dependent protein kinases. Handb. Exp. Pharmacol. 2009, 191, 1-14.

82. Fernhoff, A.N.B.; Derbyshirea, E.R.; Marletta, M.A. A nitric oxide/cysteine interaction mediates the activation of soluble guanylate cyclase. Proc. Natl. Acad. Sci. USA 2009, 106, 21602-21607. [CrossRef] [PubMed]

83. Lucas, K.A.; Pitari, G.M.; Kazerounian, S.; Ruiz-Stewart, I.; Park, J.; Schulz, S.; Chepenik, K.P.; Waldman, S.A. Guanylyl Cyclases and signaling by cyclic GMP. Pharm. Rev. 2000, 52, 375-414. [PubMed]

84. Gibb, B.J.; Wykes, V.; Garthwaite, J. Properties of NO-activated guanylyl cyclases expressed in cells. Br. J. Pharm. 2003, 139, 1032-1040. [CrossRef]

85. Sager, G. Cyclic GMP transporters. Neurochem. Int. 2004, 45, 865-873. [CrossRef]

86. Taguchi, K.; Ueda, M.; Kubo, T. Effects of cAMP and cGMP on L-type calcium channel currents in rat mesenteric artery cells. Jpn. J. Pharm. 1997, 74, 179-186. [CrossRef]

87. Heydrick, S. Nitric Oxide and the Cardiovascular System; Humana Press: Totowa, NJ, USA, 2000; pp. 33-49.

88. Busse, R.; Fleming, I. Nitric Oxide, Handbook of Experimental Pharmacology; Springer: Berlin/Heidelberg, Germany, $2000 ;$ p. 179206.

89. Waldman, S.A.; Murad, F. Cyclic GMP synthesis and function. Pharm. Rev. 1987, 39, 163-196. [PubMed]

90. Wang, G.R.; Zhu, Y.; Halushka, P.V.; Lincoln, M.T.; Mendelsohn, M.E. Mechanism of platelet inhibition by nitric oxide: In vivo phosphorylation of thromboxane receptor by cyclic GMP-dependent protein kinase. Proc. Natl. Acad. Sci. USA 1998, 95, 4888-4893. [CrossRef] [PubMed]

91. Bolotina, V.M.; Najibi, S.; Palacino, J.J.; Pagano, P.J.; Cohen, R.A. Nitric oxide directly activates calcium-dependent potassium channels in vascular smooth muscle. Nature 1994, 368, 850-853. [CrossRef]

92. Leo, M.D.; Bannister, J.P.; Narayanan, D.; Nair, A.; Grubbs, J.E.; Gabrick, K.S.; Boop, F.A.; Jaggar, J.H. Dynamic regulation of beta1 subunit trafficking controls vascular contractility. Proc. Natl. Acad. Sci. USA 2014, 111, 2361-2366. [CrossRef] [PubMed]

93. Krishnamoorthy-Natarajan, G.; Koide, M. BK Channels in the Vascular System. Int. Rev. Neurobiol. 2016, 128, 401-438.

94. Thippeswamy, T.; McKay, J.S.; Quinn, J.P.; Morris, R. Nitric Oxide, a biological double-faced janus-Is this good or bad? Histol. Histopathol. 2006, 21, 445-458. [PubMed]

95. Ahmad, A.; Dempsey, S.K.; Daneva, Z.; Azam, M.; Li, N.; Li, P.L.; Ritter, J.K. Role of Nitric Oxide in the Cardiovascular and Renal Systems. Int. J. Mol. Sci. 2018, 19, 2605. [CrossRef] [PubMed]

96. Mirabito Colafella, K.M.; Bovee, D.M.; Danser, A.H.J. The renin-angiotensin-aldosterone system and its therapeutic targets. Exp. Eye Res. 2019, 186, 107680. [CrossRef] [PubMed]

97. Kellici, T.F.; Tzakos, A.G.; Mavromoustakos, T. Rational drug design and synthesis of molecules targeting the angiotensin II type 1 and type 2 receptors. Molecules 2015, 20, 3868-3897. [CrossRef] [PubMed]

98. Ding, Y.; Chen, J.; Cui, G.; Wei, Y.; Lu, C.; Wang, L.; Diao, H. Pathophysiological role of osteopontin and angiotensin II in atherosclerosis. Biochem. Biophys. Res. Commun. 2016, 471, 5-9. [CrossRef] [PubMed] 
99. Ziegler, T.; Abdel Rahman, F.; Jurisch, V.; Kupatt, C. Atherosclerosis and the Capillary Network; Pathophysiology and Potential Therapeutic Strategies. Cells 2019, 9, 50. [CrossRef] [PubMed]

100. Loot, A.E.; Schreiber, J.G.; Fisslthaler, B.; Fleming, I. Angiotensin II impairs endothelial function via tyrosine phosphorylation of the endothelial nitric oxide synthase. J. Exp. Med. 2009, 206, 2889-2896. [CrossRef]

101. Assersen, K.B.; Sumners, C.; Steckelings, U.M. The Renin-Angiotensin System in Hypertension, a Constantly Renewing Classic: Focus on the Angiotensin AT(2)-Receptor. Can. J. Cardiol. 2020, 36, 683-693. [CrossRef] [PubMed]

102. Tóth, A.D.; Gyombolai, P.; Szalai, B.; Várnai, P.; Turu, G.; Hunyady, L. Angiotensin type 1A receptor regulates $\beta$-arrestin binding of the $\beta(2)$-adrenergic receptor via heterodimerization. Mol. Cell Endocrinol. 2017, 442, 113-124. [CrossRef]

103. Ichiki, T.; Usui, M.; Kato, M.; Funakoshi, Y.; Ito, K.; Egashira, K.; Takeshita, A. Downregulation of angiotensin II type 1 receptor gene transcription by nitric oxide. Hypertension 1998, 31, 342-348. [CrossRef] [PubMed]

104. Ahmad, A.; Sattar, M.A.; Azam, M.; Khan, S.A.; Bhatt, O.; Johns, E.J. Interaction between nitric oxide and renal $\alpha 1$-adrenoreceptors mediated vasoconstriction in rats with left ventricular hypertrophyin Wistar Kyoto rats. PLoS ONE 2018, 13, e0189386. [CrossRef]

105. Yang, J.; Sun, Y.; Dong, M.; Yang, X.; Meng, X.; Niu, R.; Guan, J.; Zhang, Y.; Zhang, C. Comparison of angiotensin-(1-7), losartan and their combination on atherosclerotic plaque formation in apolipoprotein E knockout mice. Atherosclerosis 2015, 240, 544-549. [CrossRef]

106. Sampaio, W.O.; Souza dos Santos, R.A.; Faria-Silva, R.; da Mata Machado, L.T.; Schiffrin, E.L.; Touyz, R.M. Angiotensin-(17) through receptor Mas mediates endothelial nitric oxide synthase activation via Akt-dependent pathways. Hypertension 2007, 49, 185-192. [CrossRef]

107. Walters, P.E.; Gaspari, T.A.; Widdop, R.E. Angiotensin-(1-7) acts as a vasodepressor agent via angiotensin II type 2 receptors in conscious rats. Hypertension 2005, 45, 960-966. [CrossRef] [PubMed]

108. Villela, D.; Leonhardt, J.; Patel, N.; Joseph, J.; Kirsch, S.; Hallberg, A.; Unger, T.; Bader, M.; Santos, R.A.; Sumners, C.; et al. Angiotensin type 2 receptor (AT2R) and receptor Mas: A complex liaison. Clin. Sci. 2015, 128, 227-234. [CrossRef]

109. Silva, G.M.; Franca-Falcao, M.S.; Calzerra, N.T.M.; Luz, M.S.; Gadelha, D.D.A.; Balarini, C.M.; Queiroz, T.M. Role of ReninAngiotensin System Components in Atherosclerosis: Focus on Ang-II, ACE2, and Ang-1-7. Front. Physiol. 2020, $11,1067$. [CrossRef]

110. Hamid, S.; Rhaleb, I.A.; Kassem, K.M.; Rhaleb, N.E. Role of Kinins in Hypertension and Heart Failure. Pharmaceuticals 2020, $13,347$. [CrossRef]

111. Garthwaite, J. NO as a multimodal transmitter in the brain: Discovery and current status. Br. J. Pharm. 2019, 176, 197-211. [CrossRef] [PubMed]

112. Sakai, K.; Hirooka, Y.; Matsuo, I.; Eshima, K.; Shigematsu, H.; Shimokawa, H.; Takeshita, A. Overexpression of eNOS in NTS causes hypotension and bradycardia in vivo. Hypertension 2000, 36, 1023-1028. [CrossRef] [PubMed]

113. Kishi, T.; Hirooka, Y.; Sakai, K.; Shigematsu, H.; Shimokawa, H.; Takeshita, A. Overexpression of eNOS in the RVLM causes hypotension and bradycardia via GABA release. Hypertension 2001, 38, 896-901. [CrossRef]

114. McBryde, F.D.; Liu, B.H.; Roloff, E.V.; Kasparov, S.; Paton, J.F.R. Hypothalamic paraventricular nucleus neuronal nitric oxide synthase activity is a major determinant of renal sympathetic discharge in conscious Wistar rats. Exp. Physiol. 2018, 103, 419-428. [CrossRef] [PubMed]

115. Hirooka, Y. Sympathetic Activation in Hypertension: Importance of the Central Nervous System. Am. J. Hypertens. 2020, 33, 914-926. [CrossRef]

116. Waki, H.; Kasparov, S.; Wong, L.F.; Murphy, D.; Shimizu, T.; Paton, J.F. Chronic inhibition of endothelial nitric oxide synthase activity in nucleus tractus solitarii enhances baroreceptor reflex in conscious rats. J. Physiol. 2003, 546, 233-242. [CrossRef]

117. Kimura, Y.; Hirooka, Y.; Sagara, Y.; Ito, K.; Kishi, T.; Shimokawa, H.; Takeshita, A.; Sunagawa, K. Overexpression of inducible nitric oxide synthase in rostral ventrolateral medulla causes hypertension and sympathoexcitation via an increase in oxidative stress. Circ. Res. 2005, 96, 252-260. [CrossRef] [PubMed]

118. Schwarz, P.; Diem, R.; Dun, N.J.; Förstermann, U. Endogenous and exogenous nitric oxide inhibits norepinephrine release from rat heart sympathetic nerves. Circ. Res. 1995, 77, 841-848. [CrossRef]

119. Krob, H.A.; Vinsant, S.L.; Ferrario, C.M.; Friedman, D.P. Angiotensin-(1-7) immunoreactivity in the hypothalamus of the (mRen-2d)27 transgenic rat. Brain Res. 1998, 798, 36-45. [CrossRef]

120. Zheng, H.; Liu, X.; Patel, K.P. Angiotensin-converting enzyme 2 overexpression improves central nitric oxide-mediated sympathetic outflow in chronic heart failure. Am. J. Physiol. Heart Circ. Physiol. 2011, 301, H2402-H2412. [CrossRef]

121. Patel, K.P.; Schultz, H.D. Angiotensin peptides and nitric oxide in cardiovascular disease. Antioxid. Redox Signal. 2013, 19, 1121-1132. [CrossRef]

122. Francis, S.H.; Busch, J.; Corbin, D.J. cGMP-Dependent Protein Kinases and cGMP Phosphodiesterases in Nitric Oxide and cGMP Action. Pharm. Rev. 2010, 62, 525-563. [CrossRef]

123. Feelisch, M. The use of nitric oxide donors in pharmacological studies. Naunyn-Schmiedebergs Arch. Pharmacol. 1998, 358, 113-122. [CrossRef]

124. Janero, D.R.; Bryan, N.S.; Fumito, S.; Dhawan, V.; Schwalb, D.J.; Warren, M.C.; Feelisch, M. Differential nitrosylation of blood and tissue constituents during glyceryl trinitrate biotransformation in vivo. Proc. Natl. Acad. Sci. USA 2004, 101, 16958-16963. [CrossRef] 
125. Pereira, A.C.; Araújo, A.V.; Paulo, M.; Andrade, F.A.; Silva, B.R.; Vercesi, J.A.; Silva, R.S.; Bendhack, L.M. Hypotensive effect and vascular relaxation in different arteries induced by the nitric oxide donor RuBPY. Nitric Oxide 2017, 30, 11-16. [CrossRef] [PubMed]

126. Machado, N.T.; Maciel, P.M.; Alustau, M.C.; Queiroz, T.M.; Furtado, F.F.; Assis, V.L.; Veras, R.C.; Araújo, I.G.; Athayde-Filho, P.F.; Medeiros, I.A. Nitric oxide as a target for the hypotensive and vasorelaxing effects induced by (Z)-ethyl 12-nitrooxy-octadec-9enoate in rats. Eur. J. Pharm. Sci. 2014, 62, 317-325. [CrossRef]

127. Miller, M.R.; Megson, I.L. Recent developments in nitric oxide donor drug. Br. J. Pharmacol. 2007, 151, 305-321. [CrossRef] [PubMed]

128. Ulker, S.; Mcmaster, D.; Mckeown, P.P.; Bayraktutan, U. Impaired activities of antioxidant enzymes elicit endothelial dysfunction in spontaneous hypertensive rats despite enhanced vascular nitric oxide generation. Cardiovasc. Res. 2003, 59, 488-500. [CrossRef]

129. Floryszak-Wieczorek, J.; Milczarek, G.; Arasimowicz, M.; Ciszewski, A. Do nitric oxide donors mimic endogenous NO-related response in plants? Planta 2006, 224, 1363-1372. [CrossRef] [PubMed]

130. Priviero, F.B.; Webb, R.C. Heme-dependent and independent soluble guanylate cyclase activators and vasodilation. J. Cardiovasc. Pharm. 2010, 56, 229-233. [CrossRef]

131. Kodja, G.; Feelisch, M.; Noack, E. Sulfhydryl-containing nitrate esters: A new class of nitric oxide donors. Cardiovasc Drug Rev. 1995, 13, 275-288.

132. Friederich, J.A.; Butterworth, J.F. Sodium nitroprusside: Twenty years and couting. Anesth. Analg. 1995, 81, 152-162. [PubMed]

133. Cobb, A.; Thornton, L. Sodium Nitroprusside as a Hyperinflation Drug and Therapeutic Alternatives. J. Pharm. Pract. 2018, 31, 374-381. [CrossRef]

134. Hottinger, D.G.; Beebe, D.S.; Kozhimannil, T.; Prielipp, R.C.; Belani, K.G. Sodium nitroprusside in 2014: A clinical concepts review. J. Anaesthesiol. Clin. Pharm. 2014, 30, 462-471.

135. Fukatsu, A.; Hayashi, T.; Miyazaki-Akita, A.; Matsui-Hirai, H.; Furutate, Y.; Ishitsuka, A.; Hattori, Y.; Iguchi, A. Possible Usefulness of apocynun, na NADPH oxidase inibitor, for nitrate tolerance: Prevention of NO donor-induced endotelial cell abnormalities. Am. J. Physiol. Heart Circ. Physiol. 2007, 293, 790-797. [CrossRef]

136. Yakazu, Y.; Iwasawa, K.; Narita, H.; Kindscher, J.D.; Benson, K.T.; Goto, H. Hemodynamic and sympathetic effects of feoldopam and sodium nitroprusside. Acta Anaesthesiol. A Scand. 2001, 45, 1176-1180. [CrossRef]

137. Brunton, T. On the use of nitrite of amyl in angina pectoris. Lancet 1867, 2, 97-98. [CrossRef]

138. Lindenfeld, J.; Albert, N.M.; Boehmer, J.P.; Collins, S.P.; Ezekowitz, J.A.; Givertz, M.M.; Katz, S.D.; Klapholz, M.; Moser, D.K.; Rogers, J.G.; et al. Comprehensive heart failure practice guideline. J. Card. Fail. 2010, 16, 194.

139. Fung, H.L.; Chung, S.J.; Bauer, J.A.; Chong, S.; Kowaluk, E.A. Biochemical mechanism of organic nitrate action. AJC 1992, 70, 4B-10B. [CrossRef]

140. Heidenreich, P.A.; McDonald, K.M.; Hastie, T.; Fadel, B.; Hagan, V.; Lee, B.K.; Hlatky, M.A. Meta-analysis of trials comparing $\beta$-blockers, calcium antagonists, and nitrates for stable angina. JAMA Am. Med. Assoc. 1999, 281, 1927-1936. [CrossRef]

141. Münzel, T.; Steven, S.; Daiber, A. Organic nitrates: Update on mechanisms underlying vasodilation, tolerance and endothelial dysfunction. Vasc. Pharm. 2014, 63, 105-113. [CrossRef]

142. Tarkin, J.M.; Kaski, J.C. Vasodilator Therapy: Nitrates and Nicorandil. Cardiovasc. Drugs 2017, 31, 367-378. [CrossRef]

143. Serafim, R.A.M.; Primi, M.C.; Trossini, G.H.G.; Ferreira, E.I. Nitric Oxide: State of the Art in Drug Design. Curr. Med. Chem. 2012, 19, 386-405. [CrossRef] [PubMed]

144. Zhou, R.H.; Frishman, W.H. The antiplatelet effects of nitrates: Is it of clinical significance in patients with cardiovascular disease? Cardiol. Rev. 2010, 18, 198-203. [CrossRef]

145. Omar, S.A.; Artime, E.; Webb, A.J. A comparison of organic and inorganic nitrates/nitrites. Nitric Oxide 2012, 26, 229-240. [CrossRef] [PubMed]

146. Abshagen, U.W. Pharmacokinetics of isosorbide mononitrate. Am. J. Cardiol. 1992, 27, G61-G66. [CrossRef]

147. Chen, Z.; Stamler, J.S. Bioactivation of nitroglycerin by the mitochondrial aldehyde dehydrogenase. Trends Cardiovasc. Med. 2006, 16, 259-265. [CrossRef] [PubMed]

148. Wang, P.G.; Xian, M.; Tang, X.; Wu, X.; Wen, Z.; Cai, T.; Janczuk, A.J. Nitric oxide donors: Chemical activities and biological applications. Chem. Rev. 2002, 102, 1091-1134. [CrossRef]

149. Miller, M.R.; Wadsworth, R.M. Understanding organic nitrates-A vein hope? Br. J. Pharm. 2009, 157, 565-567. [CrossRef] [PubMed]

150. França-Silva, M.S.; Balarini, C.M.; Cruz, J.C.; Khan, B.A.; Rampelotto, P.H.; Braga, V.A. Organic nitrates: Past, present and future. Molecules 2014, 19, 15314-15323. [CrossRef]

151. Lee, S.R.; Nilius, B.; Han, J. Gaseous Signaling Molecules in Cardiovascular Function: From Mechanisms to Clinical Translation. Ver. Physiol. Biochem. Pharmacol. 2018, 174, 81-156.

152. Marczin, N.; Riedel, B.; Royston, D.; Yacoub, M. Intravenous nitrate vasodilators and exhaled nitric oxide. Lancet 1997, $349,1742$. [CrossRef]

153. Kövesi, T.; Royston, D.; Yacoub, M.; Marczin, N. Basal and nitroglycerin-induced exhaled nitric oxide before and after cardiac surgery with cardiopulmonary bypass. Br. J. Anaesth. 2003, 90, 608-616. [CrossRef] [PubMed]

154. Boshier, P.R.; Hanna, G.B.; Marczin, N. Exhaled nitric oxide as biomarker of acute lung injury: An unfulfilled promise? J. Breath. Res. 2013, 7, 017118. [CrossRef] 
155. Huang, Z.; Fu, J.; Zhang, Y. Nitric Oxide Donor-Based Cancer Therapy: Advances and Prospects. J. Med. Chem. 2017, 28, 7617-7635. [CrossRef]

156. Yasuda, H.; Yamaya, M.; Nakayama, K.; Sasaki, T.; Ebihara, S.; Kanda, A.; Asada, M.; Inoue, D.; Suzuki, T.; Okazaki, T.; et al. Randomized phase II trial comparing nitroglycerin plus vinorelbine and cisplatin with vinorelbine and cisplatin alone in previously untreated stage IIIB/IV non-small-cell lung cancer. J. Clin. Oncol. 2006, 24, 688-694. [CrossRef] [PubMed]

157. Mintz, J.; Vedenko, A.; Rosete, O.; Shah, K.; Goldstein, G.; Hare, J.M.; Ramasamy, R.; Arora, H. Current Advances of Nitric Oxide in Cancer and Anticancer Therapeutics. Vaccines 2021, 9, 94. [CrossRef] [PubMed]

158. Yu, D.K.; Giesing, D.H.; Williams, R.L.; Benet, L.Z.; Lin, E.T. Pharmacokinetics of nitroglycerin and metabolites in humans following oral dosing. Biopharm. Drug Dipos. 1988, 9, 557-565. [CrossRef] [PubMed]

159. Assinder, D.F.; Chasseaud, L.F.; Taylor, T. Plasma Isosorbide Dinitrate Concentrations in Human Subjects after Administration of Standard and Sustained-Release Formulations. J. Pharm. Sci. 1977, 66, 775-778. [CrossRef] [PubMed]

160. Balasubramanian, S.; Chowdhury, Y.S. Isosorbide; StatPearls Publishing: Treasure Island, FL, USA, 2021.

161. Hashimoto, S.; Kobayashi, A. Clinical Pharmacokinetics and Pharmacodynamics of Glyceryl Trinitrate and its Metabolites. Clin. Pharm. 2003, 42, 205-221. [CrossRef]

162. Pannala, A.S.; Mani, A.R.; Spencer, J.P.E.; Skinner, V.; Bruckdorfer, K.R.; Moore, K.P.; Rice-Evans, C.A. The effect of dietary nitrate on salivary, plasma, and urinary nitrate metabolism in humans. Free Radic. Biol. Med. 2003, 34, 576-584. [CrossRef]

163. Hunault, C.C.; van Velzen, A.G.; Sips, A.J.A.M.; Schothorst, R.C.; Meulenbelt, J. Bioavailability of sodium nitrite from an aqueous solution in healthy adults. Toxicol. Lett. 2009, 190, 48-53. [CrossRef]

164. Wagner, A.D.; Schultz, D.S.; Deen, W.M.; Young, V.R.; Tannernbaum, S.R. Metabolic fate of an oral dose of $15 \mathrm{~N}-\mathrm{labeled}$ nitrate in humans: Effect of diet supplementation with ascorbic acid. Cancer Res. 1983, 43, 1921-1925.

165. Munzel, T. Explaining the Phenomenon of Nitrate Tolerance. Circ. Res. 2005, 97, 618-628. [CrossRef] [PubMed]

166. Daiber, A.; Wenzel, P.; Oelze, M.; Münzel, T. New insights into bioactivation of organic nitrates, nitrate tolerance and crosstolerance. Clin. Res. Cardiol. 2008, 97, 12-20. [CrossRef]

167. Fung, H.L. biochemical mechanism of nitroglycerin action and tolerance: Is this old mystery solved? Annu. Rev. Pharmacol. Toxicol. 2004, 44, 67-85. [CrossRef]

168. Klemenska, E.; Beresewicz, A. Bioactivation of organic nitrates and the mechanism of nitrate tolerance. Cardiol. J. 2009, 16, 11-19.

169. Lopez, M.; Malacarne, P.F.; Gajos-Draus, A.; Ding, X.; Daiber, A.; Lundberg, J.O.; Offermanns, S.; Brandes, R.P.; Rezende, F. Vascular biotransformation of organic nitrates is independent of cytochrome P450 monooxygenases. Br. J. Pharmacol. 2021, 178, 1495-1506. [CrossRef] [PubMed]

170. Cosby, K.; Partovi, K.S.; Crawford, J.H.; Patel, R.P.; Reiter, C.D.; Martyr, S.; Yang, B.K.; Waclawiw, M.A.; Zalos, G.; Xu, X.; et al. Nitrite reduction to nitric oxide by deoxyhemoglobin vasodilates the human circulation. Nat. Med. 2003, 9, 1498-1505. [CrossRef]

171. Rassaf, T.; Flogel, U.; Drexhage, C.; Hendgen-Cotta, U.; Kelm, M.; Schrader, J. Nitrite reductase function of deoxymyoglobin: Oxygen sensor and regulator of cardiac energetics and function. Circ. Res. 2007, 100, 1749-1754. [CrossRef]

172. Shiva, S.; Huang, Z.; Grubina, R.; Sun, J.; Ringwood, L.A.; MacArthur, P.H.; Xu, X.; Murphy, E.; Darley-Usmar, V.M.; Gladwin, M.T. Deoxymyoglobin is a nitrite reductase that generates nitric oxide and regulates mitochondrial respiration. Circ. Res. 2007, 100, 654-661. [CrossRef]

173. Webb, A.J.; Milsom, A.B.; Rathod, K.S.; Chu, W.L.; Qureshi, S.; Lovell, M.J.; Lecomte, F.M.; Perrett, D.; Raimondo, C.; Khoshbin, E.; et al. Mechanisms underlying erythrocyte and endothelial nitrite reduction to nitric oxide in hypoxia: Role for xanthine oxidoreductase and endothelial nitric oxide synthase. Circ. Res. 2008, 103, 957-964. [CrossRef] [PubMed]

174. Li, H.; Cui, H.; Kundu, T.K.; Alzawahra, W.; Zweier, J.L. Nitric Oxide Production from Nitrite Occurs Primarily in Tissues Not in the Blood. J. Biol. Chem. 2008, 283, 17855-17863. [CrossRef]

175. Aamand, R.; Dalsgaard, T.; Jensen, F.B.; Simonsen, U.; Roepstorff, A.; Fago, A. Generation of nitric oxide from nitrite by carbonic anhydrase: A possible link between metabolic activity and vasodilation. Am. J. Physiol.-Heart Circ. Physiol. 2009, 297, H2068-H2074. [CrossRef]

176. Kapil, V.; Haydar, S.M.A.; Pearl, V.; Lundberg, J.O.; Weitzberg, E.; Ahluwalia, A. Physiological role for nitrate-reducing oral bacteria in blood pressure control. Free Radic. Biol. Med. 2013, 55, 93-100. [CrossRef]

177. Moretti, C.; Zhuge, Z.; Zhang, G.; Haworth, S.M.; Paulo, L.L.; Guimarães, D.D.; Lundberg, J.O. The obligatory role of host microbiota in bioactivation of dietary nitrate. Free Radic. Biol. Med. 2019, 145, 342-348. [CrossRef] [PubMed]

178. Dejam, A.; Hunter, C.J.; Tremonti, C.; Pluta, R.M.; Hon, Y.Y.; Grimes, G.; Gladwin, M.T. Nitrite Infusion in Humans and Nonhuman Primates: Endocrine Effects, Pharmacokinetics, and Tolerance Formation. Circulation 2007, 116, 1821-1831. [CrossRef]

179. Magee, P.N.; Barnes, J.M. The Production of Malignant Primary Hepatic Tumours in the Rat by Feeding Dimethylnitrosamine. Br. J. Cancer 1956, 10, 114-122. [CrossRef]

180. Oelze, M.; Knorr, M.; Kröller-Schön, S.; Kossmann, S.; Gottschlich, A.; Rümmler, R.; Schuff, A.; Daub, S.; Doppler, C.; Kleinert, H.; et al. Chronic therapy with isosorbide-5-mononitrate causes endothelial dysfunction, oxidative stress, and a marked increase in vascular endothelin-1 expression. Eur. Heart J. 2013, 34, 3206-3216. [CrossRef] [PubMed]

181. Münzel, T. Effects of long-term nitroglycerin treatment on endothelial nitric oxide synthase (NOS III) gene expression, NOS III-mediated superoxide production, and vascular NO bioavailability. Circ. Res. 2000, 86, E7-E12. [CrossRef]

182. Preik, M.; Kelm, M.; Feelisch, M.; Strauer, B.E. Impaired effectiveness of nitric oxide-donors in resistance arteries of patients with arterial hypertension. J. Hypertens. 1996, 14, 903-908. [CrossRef] 
183. Evora, P.R.; Evora, P.M.; Celotto, A.C.; Rodrigues, A.J.; Joviliano, E.E. Cardiovascular therapeutics targets on the NO-sGC-cGMP signaling pathway: A critical overview. Curr. Drug Targets 2012, 13, 1207-1214. [CrossRef] [PubMed]

184. Münzel, T.; Giaid, A.; Kurz, S.; Stewart, D.J.; Harrison, D.G. Evidence for a role of endothelin 1 and protein kinase C in nitroglycerin tolerance. Proc. Natl. Acad. Sci. USA 1995, 92, 5244-5248. [CrossRef]

185. Divakaran, S.; Loscalzo, J. The Role of Nitroglycerin and Other Nitrogen Oxides in Cardiovascular Therapeutics. J. Am. Coll. Cardiol. 2017, 70, 2393-2410. [CrossRef] [PubMed]

186. Gori, T.; Burstein, J.M.; Ahmed, S.; Miner, S.E.S.; Al-Hesayen, A.; Kelly, S.; Parker, J.D. Folic acid prevents nitroglycerin-induced nitric oxide synthase dysfunction and nitrate tolerance: A human in vivo study. Circulation 2001, 104, 1119-1123. [CrossRef]

187. Rapoport, R.M.; Waldman, S.A.; Ginsburg, R.; Molina, C.R.; Murad, F. Effects of glyceryl trinitrate on endothelium-dependent and -independent relaxation and cyclic GMP levels in rat aorta and human coronary artery. J. Cardiovasc. Pharm. 1988, 1987, 82-89. [CrossRef]

188. Zhang, J.; Chen, Z.; Cobb, F.R.; Stamler, J.S. Role of mitochondrial aldehyde dehydrogenase in nitroglycerin-induced vasodilation of coronary and systemic vessels: An intact canine model. Circulation 2004, 110, 750-755. [CrossRef]

189. Parker, J.D.; Farrell, B.; Fenton, T.; Cohanim, M.; Parker, J.O. Counter-regulatory responses to continuous and intermittent therapy with nitroglycerin. Circulation 1991, 84, 2336-2345. [CrossRef] [PubMed]

190. Gori, T.; Al-Hesayen, A.; Courtney, J.; Parker, J.D. Comparison of the effects of pentaerythritoltetranitrate and nitroglycerin on endothelium-dependent vasorelaxation in male volunteers. Am. J. Cardiol. 2003, 91, 1392-1394. [CrossRef]

191. Jurt, U.; Goti, T.; Ravandi, A.; Babaei, S.; Zeman, P.; Parker, J.D. Differential effects of pentaerythritoltetranitrate and nitroglycerin on the development of tolerance and evidence of lipid peroxidation: A human in vivo study. J. Am. Coll. Cardiol. 2001, 38, 854-859. [CrossRef]

192. Müllenheim, J.; Müller, S.; Laber, U.; Thämer, V.; Meyer, W.; Bassenge, E.; Fink, B.; Kojda, G. The effect of high-dose pentaerythritoltetranitrate on the development of nitrate tolerance in rabbits. Naunyn-Schmiedebergs Arch. Pharmacol. 2001, 364, $269-275$.

193. Dikalov, S.; Fink, B.; Skatchkov, M.; Bassenge, E. Comparison of glyceryl trinitrate-induced with pentaerythrityl tetranitrateinduced in vivo formation of superoxide radicals: Effect of vitamin C. Free Radic. Biol. Med. 1999, 27, 170-176. [CrossRef]

194. Daiber, A.; Oelze, M.; Coldewey, M.; Bachschmid, M.; Wenzel, P.; Sydow, K.; Wendt, M.; Kleschyov, A.L.; Stalleicken, D.; Ullrich, V.; et al. Oxidative stress and mitochondrial aldehyde dehydrogenase activity: A comparison of pentaerythritol tetranitrate with other organic nitrates. Mol. Pharm. 2004, 66, 1372-1382. [CrossRef]

195. Steven, S.; Oelze, M.; Brandt, M.; Ullmann, E.; Kröller-Schön, S.; Heeren, T.; Daiber, A. Pentaerythritol Tetranitrate In Vivo Treatment Improves Oxidative Stress and Vascular Dysfunction by Suppression of Endothelin-1 Signaling in MonocrotalineInduced Pulmonary Hypertension. Oxidative Med. Cell. Longev. 2017, 2017, 4353462. [CrossRef]

196. Fraccarollo, D.; Galuppo, P.; Neuser, J.; Bauersachs, J.; Widder, J.D. Pentaerythritol Tetranitrate Targeting Myocardial Reactive Oxygen Species Production Improves Left Ventricular Remodeling and Function in Rats with Ischemic Heart Failure Novelty and Significance. Hypertension 2015, 66, 978-987. [CrossRef] [PubMed]

197. Wu, Z.; Siuda, D.; Xia, N.; Reifenberg, G.; Daiber, A.; Münzel, T.; Li, H. Maternal Treatment of Spontaneously Hypertensive Rats With Pentaerythritol Tetranitrate Reduces Blood Pressure in Female off spring Novelty and Significance. Hypertension 2014, 65, 232-237. [CrossRef] [PubMed]

198. Man, A.W.C.; Chen, M.; Wu, Z.; Reifenberg, G.; Daiber, A.; Münzel, T.; Li, H. Renal Effects of Fetal Reprogramming with Pentaerythritol Tetranitrate in Spontaneously Hypertensive Rats. Front. Pharmacol. 2020, 11, 454. [CrossRef]

199. Man, A.W.C.; Chen, M.; Zhou, Y.; Wu, Z.; Reifenberg, G.; Daiber, A.; Li, H. Fetal programming effects of pentaerythritol tetranitrate in a rat model of superimposed preeclampsia. J. Mol. Med. 2020, 98, 1287-1299. [CrossRef]

200. Bohn, H.; Schönafinger, K. Oxygen and oxidation promote the release of nitric oxide from sydnonimines. J. Cardiovasc. Pharm. 1989, 14 (Suppl. 11), S6-S12. [CrossRef]

201. Noack, E.; Feelisch, M. Molecular aspects underlying the vasodilator action of molsidomine. J. Cardiovasc. Pharm. 1989, 14 (Suppl. 11), S1-S5. [CrossRef]

202. Kristek, F.; Fiberov, V.; Varga, I. Long-Term Effect of Molsidomine and Pentaerythrityl Tetranitrate on Cardiovascular System of Spontaneously Hypertensive Rats. Physiol. Res. 2003, 52, 709-717. [PubMed]

203. Benigni, A.; Zoja, C.; Noris, M.; Corna, D.; Benedetti, G.; Bruzzi, I.; Todeschini, M.; Remuzzi, G. Renoprotection by nitric oxide donor and lisinopril in the remnant kidney model. Am. J. Kidney Dis. 1999, 33, 746-753. [CrossRef]

204. Oosterhuis, N.R.; Bongartz, L.G.; Verhaar, M.C.; Cheng, C.; Xu, Y.J.; van Koppen, A.; Cramer, M.J.; Goldsschmeding, R.; Gaillard, C.A.; Doevendans, P.P.; et al. Targeting multiple pathways reduces renal and cardiac fibrosis in rats with subtotal nephrectomy followed by coronary ligation. Acta Physiol. 2017, 220, 382-393. [CrossRef] [PubMed]

205. Reinero, M.; Beghetti, M.; Tozzi, P.; von Segesser, L.K.; Samaja, M.; Milano, G. Nitric Oxide-cGMP Pathway Modulation in an Experimental Model of Hypoxic Pulmonary Hypertension. J. Cardiovasc. Pharmacol. Ther. 2021, 107424842110141. [CrossRef]

206. Koeners, M.P.; Braam, B.; van der Giezen, D.M.; Goldschmeding, R.; Joles, J.A. A perinatal nitric oxide donor increases renal vascular resistance and ameliorates hypertension and glomerular injury in adult fawn-hooded hypertensive rats. Am. J. Physiol.-Regul. Integr. Comp. Physiol. 2008, 294, R1847-R1855. [CrossRef]

207. Lablanche, J.M.; Grollier, G.; Lusson, J.R.; Bassand, J.P.; Drobinski, G.; Bertrand, B.; Battaglia, S.; Desveaux, B.; Juillière, Y.; Juliard, J.M.; et al. Effect of the direct nitric oxide donors linsidomine and molsidomine on angiographic restenosis after coronary balloon angioplasty. The ACCORD Study. Circulation 1997, 95, 83-89. [CrossRef] 
208. Belhassen, L.; Carville, C.; Pelle, G.; Sediame, S.; Benacerraf, S.; Dubois-Rande, J.L.; Adnot, S. Molsidomine improves flowdependent vasodilation in brachial arteries of patients with coronary artery disease. J. Cardiovasc. Pharmacol. 2000, 35, 560-563. [CrossRef]

209. Van Hove, C.; Carreer-Bruhwyler, F.; Geczy, J.; Herman, A.G. Long-term treatment with the NO-donor molsidomine reduces circulating ICAM-1 levels in patients with stable angina. Atherosclerosis 2005, 180, 399-405. [CrossRef]

210. Cirino, G.; Distrutti, E.; Wallace, J.L. Nitric oxide and inflammation. Inflamm. Allergy Drug Targets 2006, 5, 115-119. [CrossRef] [PubMed]

211. Wattanapitayakul, S.K.; Weinstein, D.M.; Holycross, B.J.; Bauer, J.A. Endothelial dysfunction and peroxynitrite formation are early events in angiotensin-induced cardiovascular disorders. FASEB J. 2000, 14, 271-278. [CrossRef]

212. Szabó, C.; Ischiropoulos, H.; Radi, R. Peroxynitrite: Biochemistry, pathophysiology and development of therapeutics. Nat. Rev. Drug Discov. 2007, 6, 662-680. [CrossRef] [PubMed]

213. Bachschmid, M.; Schildknecht, S.; Ullrich, V. Redox regulation of vascular prostanoid synthesis by the nitric oxide-superoxide system. Biochem. Biophys. Res. Commun. 2005, 338, 536-542. [CrossRef]

214. Schildknecht, S.; Ullrich, V. Peroxynitrite as regulator of vascular prostanoid synthesis. Arch. Biochem. Biophys. 2009, 484, 183-189. [CrossRef] [PubMed]

215. Eligini, S.; Colli, S.; Habib, A.; Aldini, G.; Altomare, A.; Banfi, C. Cyclooxygenase-2 Glycosylation Is Affected by Peroxynitrite in Endothelial Cells: Impact on Enzyme Activity and Degradation. Antioxidants 2021, 10, 496. [CrossRef]

216. Hogg, N. The biochemistry and physiology of S-nitrosothiols. Annu Rev. Pharm. Toxicol. 2002, 42, 585-600. [CrossRef] [PubMed]

217. Hogg, N.; Darley-Usmar, V.M.; Wilson, M.T.; Moncada, S. Production of hydroxyl radicals from the simultaneous generation of superoxide and nitric oxide. Biochem. J. 1992, 281, 419-424. [CrossRef]

218. Dawson, V.L.; Dawson, T.M.; London, E.D.; Bredt, D.S.; Snyder, S.H. Nitric oxide mediates glutamate neurotoxicity in primary cortical cultures. Proc. Natl. Acad. Sci. USA 1991, 88, 6368-6371. [CrossRef]

219. Yamada, M.; Momose, K.; Richelson, E.; Yamada, M. Sodium nitroprusside-induced apoptotic cellular death via production of hydrogen peroxide in murine neuroblastoma N1E-115 cells. J. Pharm. Toxicol. Methods 1996, 35, 11-17. [CrossRef]

220. Terwel, D.; Nieland, L.J.; Schutte, B.; Reutelingsperger, C.P.; Ramaekers, F.C.; Steinbusch, H.W. S-nitroso-N-acetylpenicillamine and nitroprusside induce apoptosis in a neuronal cell line by the production of different reactive molecules. Eur. J. Pharm. 2000, 400, 19-33. [CrossRef]

221. Godínez-Rubí, M.; Rojas-Mayorquín, A.E.; Ortuño-Sahagún, D. Nitric oxide donors as neuroprotective agents after an ischemic stroke-related inflammatory reaction. Oxid. Med. Cell Longev. 2013, 2013, 297357. [CrossRef]

222. Katsuyama, K.; Shichiri, M.; Marumo, F.; Hirata, Y. NO inhibits cytokine-induced iNOS expression and NF-kappaB activation by interfering with phosphorylation and degradation of IkappaB-alpha. Arter. Thromb. Vasc. Biol. 1998, 18, 1796-1802. [CrossRef]

223. Blais, V.; Rivest, S. Inhibitory action of nitric oxide on circulating tumor necrosis factor-induced NF-kappaB activity and COX-2 transcription in the endothelium of the brain capillaries. J. Neuropathol. Exp. Neurol. 2001, 60, 893-905. [CrossRef] [PubMed]

224. De Caterina, R.; Libby, P.; Peng, H.B.; Thannickal, V.J.; Rajavashisth, T.B.; Gimbrone, M.A., Jr.; Shin, W.S.; Liao, J.K. Nitric oxide decreases cytokine-induced endothelial activation. Nitric oxide selectively reduces endothelial expression of adhesion molecules and proinflammatory cytokines. J. Clin. Investig. 1995, 96, 60-68. [CrossRef] [PubMed]

225. Walley, K.R.; McDonald, T.E.; Higashimoto, Y.; Hayashi, S. Modulation of proinflammatory cytokines by nitric oxide in murine acute lung injury. Am. J. Respir. Crit. Care Med. 1999, 160, 698-704. [CrossRef]

226. Park, S.W.; Huq, M.D.; Hu, X.; Wei, L.N. Tyrosine nitration on p65: A novel mechanism to rapidly inactivate nuclear factor-kappaB. Mol. Cell Proteom. 2005, 4, 300-309. [CrossRef] [PubMed]

227. Gasco, A.; Fruttero, R.; Sorba, G.; Stilo, A.D.; Calvino, R. NO donors: Focus on furoxan derivatives. Pure Appl. Chem. 2004, 76, 973-981. [CrossRef]

228. França-Silva, M.S.; Monteiro, M.M.; Queiroz, T.M.; Santos, A.F.; Athayde-Filho, P.F.; Braga, V.A. The new nitric oxide donor 2-nitrate-1,3-dibuthoxypropan alters autonomic function in spontaneously hypertensive rats. Auton. Neurosci. 2012, 171, 28-35. [CrossRef]

229. Queiroz, T.M.; Mendes-Júnior, L.G.; Guimarães, D.D.; França-Silva, M.S.; Nalivaiko, E.; Braga, V.A. Cardiorespiratory effects induced by 2-nitrate-1,3-dibuthoxypropan are reduced by nitric oxide scavenger in rats. Auton. Neurosci. 2014, 181, 31-36. [CrossRef]

230. Porpino, S.K.; Zollbrecht, C.; Peleli, M.; Montenegro, M.F.; Brandão, M.C.; Athayde-Filho, P.F.; França-Silva, M.S.; Larsson, E.; Lundberg, J.O.; Weitzberg, E.; et al. Nitric oxide generation by the organic nitrate NDBP attenuates oxidative stress and angiotensin II-mediated hypertension. Br. J. Pharmacol. 2016, 173, 2290-2302. [CrossRef] [PubMed]

231. De Gaitani, C.M.; de Melo, M.C.; Lunardi, C.N.; de Oliveira, F.S.; da Silva, R.S.; Bendhack, L.M. Hypotensive effect of the nitrosyl ruthenium complex nitric oxide donor in renal hypertensive rats. Nitric Oxide 2009, 20, 195-199. [CrossRef]

232. Rodrigues, G.J.; Pereira, A.C.; Vercesi, J.A.; Lima, R.G.; Silva, R.S.; Bendhack, L.M. Long-lasting hypotensive effect in renal hypertensive rats induced by nitric oxide released from a ruthenium complex. J. Cardiovasc. Pharmacol. 2012, 60, 193-198. [CrossRef] [PubMed]

233. Munhoz, F.C.; Potje, S.R.; Pereira, A.C.; Daruge, M.G.; da Silva, R.S.; Bendhack, L.M.; Antoniali, C. Hypotensive and vasorelaxing effects of the new NO donor [Ru(terpy)(bdq) $\left.\mathrm{NO}^{+}\right]^{3+}$ in spontaneously hypertensive rats. Nitric Oxide 2012, 26, 111-117. [CrossRef] 
234. Potje, S.R.; Troiano, J.A.; Grando, M.D.; Graton, M.E.; da Silva, R.S.; Bendhack, L.M.; Antoniali, C. Endothelial modulation of a nitric oxide donor complex-induced relaxation in normotensive and spontaneously hypertensive rats. Life Sci. 2018, 201, 130-140. [CrossRef]

235. Das Mendes-Júnior, L.G.; Guimarães, D.D.; Gadelha, D.D.; Diniz, T.F.; Brandão, M.C.; Athayde-Filho, P.F.; Lemos, V.S.; França-do Silva, M.S.; Braga, V.A. The new nitric oxide donor cyclohexane nitrate induces vasorelaxation, hypotension, and antihypertensive effects via NO/cGMP/PKG pathway. Front. Physiol. 2015, 6, 243. [CrossRef]

236. Paulo, L.L.; Cruz, J.C.; Zhuge, Z.; Carvalho-Galvão, A.; Brandão, M.C.R.; Diniz, T.F.; Haworth, S.M.; Athayde-Filho, P.F.; Lemos, V.S.; Lundberg, J.O.; et al. The novel organic mononitrate NDHP attenuates hypertension and endothelial dysfunction in hypertensive rats. Redox Biol. 2018, 15, 182-191. [CrossRef]

237. Orvid, C.; Abrams, M.J. Medicinal inorganic chemistry: Introduction. Chem. Rev. 1999, 99, 2201-2204.

238. Silva, D.O. Perspectives for movel mixed diruthenium-organic drug as metallopharmaceuticals in cancer therapy. Anticancer Agents Med. Chem. 2010, 10, 312-323. [CrossRef]

239. Bruijnincx, P.C.A.; Sadler, P.J. New trends for metal complexes with anticancer activity. Curr. Opin. Chem. Biol. 2008, 12, 197-206. [CrossRef]

240. Hambley, T.W. Developing new metal-based therapeutics: Challenges and opportunities. Dalton Trans. 2007, $21,4929-4937$. [CrossRef]

241. Meggers, E. Targeting proteins with metal complexes. Chem. Commun. 2009, 7, 1001-1100. [CrossRef] [PubMed]

242. Dwyer, F.P.; Mayhew, E.; Roe, E.M.; Shulman, A. Inhibition of landschuetz ascites tumour growth by metal chelates derived from 3,4,7,8-Tetramethyl-1,10-phenanthroline. Br. J. Cancer 1965, 19, 195-199. [CrossRef]

243. Bonaventura, D.; Oliveira, F.d.S.; Togniolo, V.; Tedesco, A.C.; da Silva, R.S.; Bendhack, L.M. A macrocyclic nitrosyl ruthenium complex is a NO donor that induces rat aorta relaxation. Nitric Oxide 2004, 10, 83-91. [CrossRef] [PubMed]

244. Bonaventura, D.; Oliveira, F.S.; Lunardi, C.N.; Vercesi, J.A.; da Silva, R.S.; Bendhack, L.M. Characterization of the mechanisms of action and nitric oxide species involved in the relaxation induced by the ruthenium complex. Nitric Oxide 2006, 15, 387-394. [CrossRef] [PubMed]

245. Bonaventura, D.; de Lima, R.G.; Vercesi, J.A.; da Silva, R.S.; Bendhack, L.M. Comparison of the mechanisms underlying the relaxation induced by two nitric oxide donors: Sodium nitroprusside and a new ruthenium complex. Vasc. Pharm. 2007, 46, 215-222. [CrossRef]

246. Paulo, M.; Rodrigues, G.J.; da Silva, R.S.; Bendhack, L.M. A new NO donor failed to release NO and to induce relaxation in the rat basilar artery. Eur. J. Pharm. Sci. 2012, 45, 344-350. [CrossRef]

247. Potje, S.R.; Munhoz, F.C.; Perassa, L.A.; Graton, M.E.; Pereira, A.A.; Nakamune, A.C.; da Silva, R.S.; Bendhack, L.M.; Sumida, D.H.; Antoniali, C. Mechanisms underlying the hypotensive and vasodilator effects of Ru(terpy)(bdq)NO] ${ }^{3+}$, a nitric oxide donor, differ between normotensive and spontaneously hypertensive rats. Eur. J. Pharm. Sci. 2014, 741, 222-229. [CrossRef] [PubMed]

248. Costa, P.P.C.; Campos, R.; Cabral, P.H.B.; Gomes, V.M.; Santos, C.F.; Waller, S.B.; de Sousa, E.H.S.; Lopes, L.G.F.; Fonteles, M.C.; do Nascimento, N.R.F. Antihypertensive potential of cis-[Ru(bpy) $2(\operatorname{ImN})(\mathrm{NO})]^{3+}$, a ruthenium-based nitric oxide donor. Res. Vet. Sci. 2020, 130, 153-160. [CrossRef]

249. Marcondes, F.G.; Ferro, A.A.; Souza-Torsoni, A.; Sumitani, M.; Clarke, M.J.; Franco, D.W.; Tfouni, E.; Krieger, M.H. In vivo effects of the controlled NO donor/scavenger ruthenium cyclam complexes on blood pressure. Life Sci. 2002, 70, 2735-2752. [CrossRef]

250. Olesen, J.; Thomsen, L.L.; Iversen, H. Nitric oxide is a key molecule in migraine and other vascular headaches. Trends Pharm. Sci. 1994, 15, 149-153. [CrossRef]

251. Araújo, A.V.; Pereira, A.C.; Grando, M.D.; da Silva, R.D.; Bendhack, L.M. The new NO donor Terpy in-duces similar relaxation in mesenteric resistance arteries of renal hyper-tensive and normotensive rats. Nitric Oxide 2013, 35, 47-53. [CrossRef] [PubMed]

252. Bonaventura, D.; de Lima, R.G.; da Silva, R.S.; Bendhack, L.M. NO donors-relaxation is impaired in aorta from hypertensive rats due to a reduced involvement of $\mathrm{K}(+)$ channels and sarcoplasmic reticulum Ca(2+)-ATPase. Life Sci. 2011, 89, 595-602. [CrossRef]

253. Potje, S.R.; Chen, Z.; Oliveira, S.D.S.; Bendhack, L.M.; da Silva, R.S.; Bonini, M.G.; Antoniali, C.; Minshall, R.D. Nitric oxide donor $\left[\mathrm{Ru}(\text { terpy)(bdq)NO}]^{3+}\right.$ induces uncoupling and phosphorylation of endothelial nitric oxide synthase promoting oxidant production. Free Radic. Biol. Med. 2017, 112, 587-596. [CrossRef] [PubMed]

254. Potje, S.R.; Hildebrand, M.C.; Munhoz, F.C.; Troiano, J.A.; Pereira, A.A.; Nakamune, A.C.; da Silva, R.S.; Bendhack, L.M.; Antoniali, C. The hypotensive effect of the ruthenium complex $\left[\mathrm{Ru}(\text { terpy)(bdq)NO}]^{3+}\right.$ is higher in male than in female spontaneously hypertensive rats (SHR). Naunyn-Schmiedebergs Arch. Pharmacol. 2014, 387, 1045-1051. [CrossRef] [PubMed]

255. Pereira, A.C.; Ford, P.C.; da Silva, R.S.; Bendhack, L.M. Ruthenium-nitrite complex as pro-drug releases NO in a tissue and enzyme-dependent way. Nitric Oxide 2011, 24, 192-198. [CrossRef]

256. Pereira, A.C.; Lunardi, C.N.; Paulo, M.; da Silva, R.S.; Bendhack, L.M. Nitric oxide generated by the compound RuBPY promotes the vascular smooth cell membrane hyperpolarization. Eur. J. Pharm. Sci. 2013, 48, 604-610. [CrossRef]

257. Paulo, M.; Grando, M.D.; da Silva, R.S.; Minshall, R.D.; Bendhack, L.M. The nitric oxide donor RuBPY does not induce in vitro cross-tolerance with acetylcholine. Nitric Oxide 2017, 69, 69-77. [CrossRef]

258. Crisalli, A.M.; Franco, L.P.; Silva, B.R.; Holanda, A.K.M.; Bendhack, L.M.; Da Silva, R.S.; Ford, P.C. Nitric oxide release from a photoactive water-soluble ruthenium nitrosyl. Biological effects. J. Coord. Chem. 2018, 71, 1690-1703. [CrossRef] 
259. Oishi, J.C.; Buzinnari, T.C.; Pestana, C.R.; De Moraes, T.F.; Vatanabe, I.P.; Wink, D.A., Jr.; da Silva, R.S.; Bendhack, L.M.; Rodrigues, G.J. In Vitro Treatment with cis- $\left[\mathrm{Ru}(\mathrm{H}-\mathrm{dcbpy}-)_{2}(\mathrm{Cl})(\mathrm{NO})\right]$ Improves the Endothelial Function in Aortic Rings with Endothelial Dysfunction. J. Pharm. Pharm. Sci. 2015, 18, 696-704. [CrossRef] [PubMed]

260. Campelo, M.W.; Campelo, A.P.; Lopes, L.G.; Santos, A.A.; Guimarães, S.B.; Vasconcelos, P.R. Effects of Rut-bpy (Cis$\left.\left[\mathrm{Ru}(\mathrm{bpy})_{2}\left(\mathrm{SO}_{3}\right)(\mathrm{NO})\right] \mathrm{PF}_{6}\right)$, a novel nitric oxide donor, in L-NAME-induced hypertension in rats. Acta Cir. Bras. 2011, 26, 57-59. [CrossRef] [PubMed]

261. Cerqueira, J.B.; Silva, L.F.; Lopes, L.G.; Moraes, M.E.; Nascimento, N.R. Relaxation of rabbit corpus cavernosum smooth muscle and aortic vascular endothelium induced by new nitric oxide donor substances of the nitrosyl-ruthenium complex. Int. Braz. J. Urol. 2008, 34, 638-647. [CrossRef]

262. Costa, P.P.C.; Waller, S.B.; Dos Santos, G.R.; Gondim, F.L.; Serra, D.S.; Cavalcante, F.S.A.; Gouveia, F.S., Jr.; de Paula, V.F., Jr.; Sousa, E.H.S.; Lopes, L.G.F.; et al. Anti-asthmatic effect of nitric oxide metallo-donor FOR811A [cis-[Ru(bpy $\left.\left.)_{2}(2-\mathrm{MIM})\left(\mathrm{NO}^{2}\right)\right](\mathrm{PF} 6)_{3}\right]$ in the respiratory mechanics of Swiss mice. PLoS ONE 2021, 16, e0248394. [CrossRef]

263. Sasahara, G.L.; Gouveia Junior, F.S.; Rodrigues, R.O.; Zampieri, D.S.; Fonseca, S.; Goncalves, R.C.R.; Athaydes, B.R.; Kitagawa, R.R.; Santos, F.A.; Sousa, E.H.S.; et al. Nitro-imidazole-based ruthenium complexes with antioxidant and anti-inflammatory activities. J. Inorg. Biochem. 2020, 206, 111048. [CrossRef] [PubMed]

264. Leitão Junior, A.S.; Campos, R.M.; Cerqueira, J.B.; Fonteles, M.C.; Santos, C.F.; de Nucci, G.; Sousa, E.H.; Lopes, L.G.; GonzagaSilva, L.F.; Nascimento, N.R. Relaxant effect of a metal-based drug in human corpora cavernosa and its mechanism of action. Int. J. Impot Res. 2016, 27, 181-187. [CrossRef] [PubMed] 